University of South Florida

DIGITAL COMMONS

Digital Commons @ University of

@ UNIVERSITY OF SOUTH FLORIDA

South Florida

$1-1-2010$

\title{
2010 Annual Report USF Polytechnic
}

USF

Follow this and additional works at: https://digitalcommons.usf.edu/usf_accountability_reports

\section{Scholar Commons Citation}

USF, "2010 Annual Report USF Polytechnic" (2010). USF Accountability Reports. 6.

https://digitalcommons.usf.edu/usf_accountability_reports/6

This Article is brought to you for free and open access by the USF Archives at Digital Commons @ University of South Florida. It has been accepted for inclusion in USF Accountability Reports by an authorized administrator of Digital Commons @ University of South Florida. For more information, please contact digitalcommons@usf.edu. 


\title{
University of South Florida--Polytechnic
}

\author{
Approved by the USF System BOT, December 16th, 2010
}




\begin{tabular}{|c|c|c|c|c|c|c|c|}
\hline \multicolumn{8}{|c|}{ University of South Florida 2010 Annual Report } \\
\hline & & & \multicolumn{5}{|c|}{ USF Polytechnic } \\
\hline Enrollments & \# & $\%$ & \multicolumn{3}{|c|}{ Degree Programs Offered (As of Spr. 10) } & \multicolumn{2}{|c|}{ Carnegie Classification } \\
\hline $\begin{array}{l}\text { TOTAL } \\
\text { (Fall 2009) }\end{array}$ & 1,299 & $100 \%$ & \multicolumn{2}{|l|}{ TOTAL } & 16 & $\begin{array}{c}\text { Undergraduate } \\
\text { Instructional Program: }\end{array}$ & \multirow{10}{*}{$\begin{array}{c}\text { SEPARATE CLASSIFICATION } \\
\text { PENDING }\end{array}$} \\
\hline Black & 129 & $10 \%$ & \multicolumn{2}{|c|}{ Baccalaureate } & 11 & Graduate Instructional & \\
\hline Hispanic & 124 & $10 \%$ & \multicolumn{2}{|c|}{ Master's \& Specialist's } & 5 & Program: & \\
\hline White & 976 & $75 \%$ & \multicolumn{2}{|c|}{ Research Doctorate } & 0 & Enrollment Profile: & \\
\hline Other & 70 & $5 \%$ & \multicolumn{2}{|c|}{ Professional Doctorate } & 0 & Undergraduate Profile: & \\
\hline Full-Time & 509 & $39 \%$ & \multirow{2}{*}{$\begin{array}{l}\text { Faculty } \\
\text { (Fall 2009) }\end{array}$} & \multirow{2}{*}{$\begin{array}{l}\text { Full- } \\
\text { Time }\end{array}$} & \multirow{2}{*}{ Part-Time } & Size and Setting: & \\
\hline Part-Time & 790 & $61 \%$ & & & & \multirow{2}{*}{ Basic: } & \\
\hline Undergraduate & 1,055 & $81 \%$ & TOTAL & 30 & 5 & & \\
\hline Graduate & 201 & $15 \%$ & Tenure/T. Track & 19 & 0 & \multirow{2}{*}{ Elective Classification: } & \\
\hline Unclassified & 43 & $3 \%$ & Other Faculty/Instr. & 11 & 5 & & \\
\hline
\end{tabular}

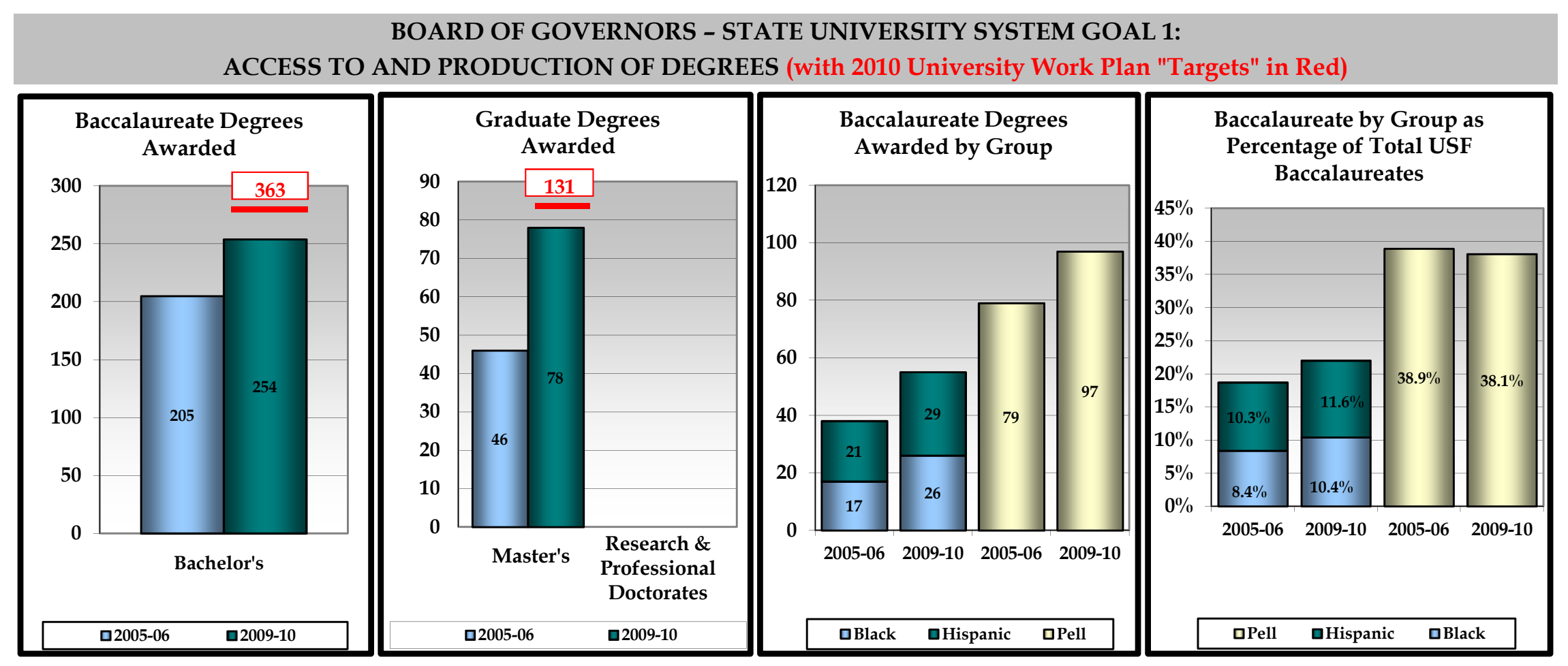

2012 - 2013 Projected Institutional Contributions in RED PRINT. 
BOARD OF GOVERNORS - STATE UNIVERSITY SYSTEM GOAL 2:

MEETING STATEWIDE PROFESSIONAL AND WORKFORCE NEEDS (with 2010 University Work Plan "Targets" in Red)

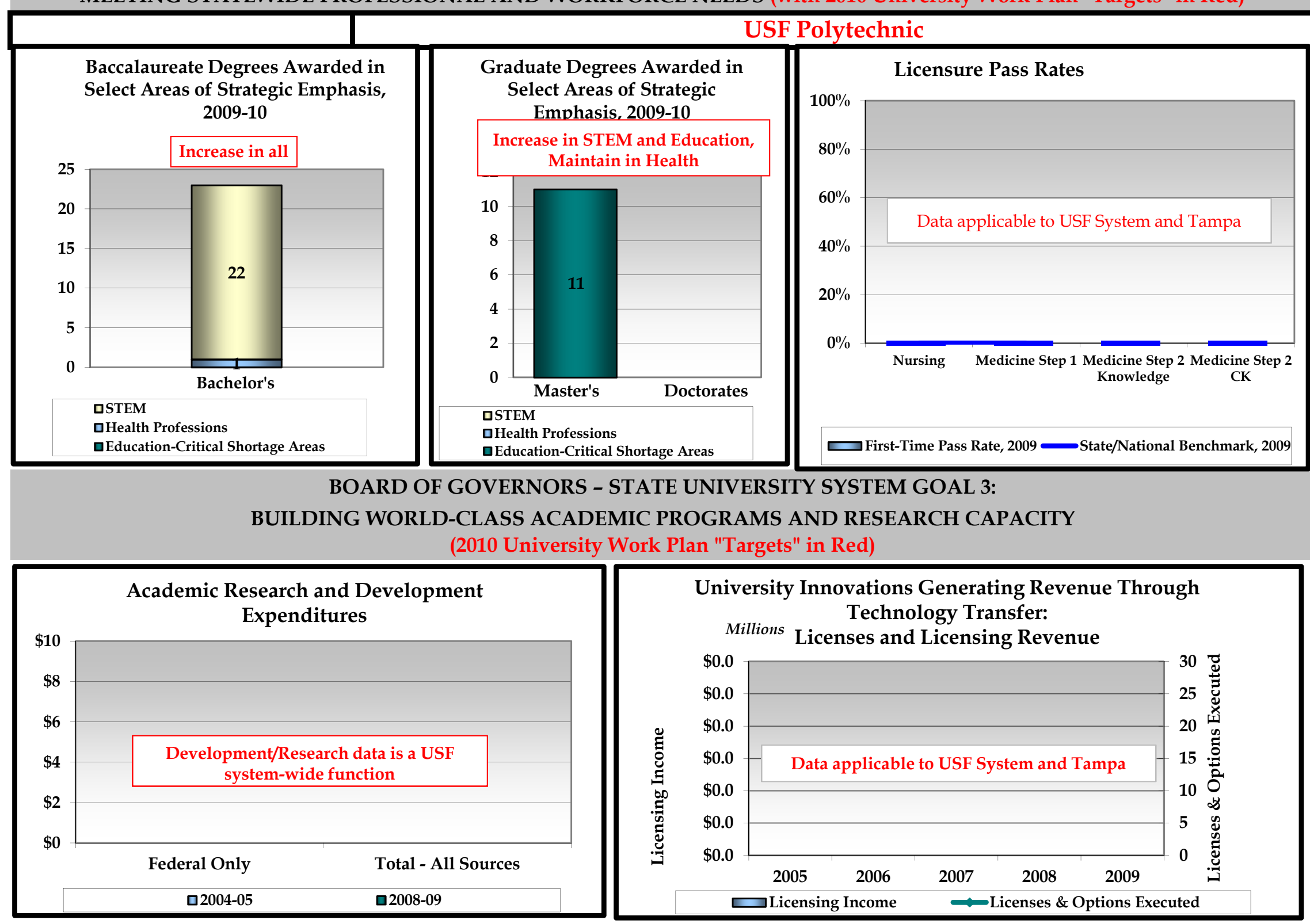

Projected Institutional Contributions in RED PRINT

(2012 - 2013 for TOTAL Degrees in Areas of Strategic Emphasis; 2012 for NCLEX; 2011 -2012 for R\&D, Licences, and Licensing Revenue). 


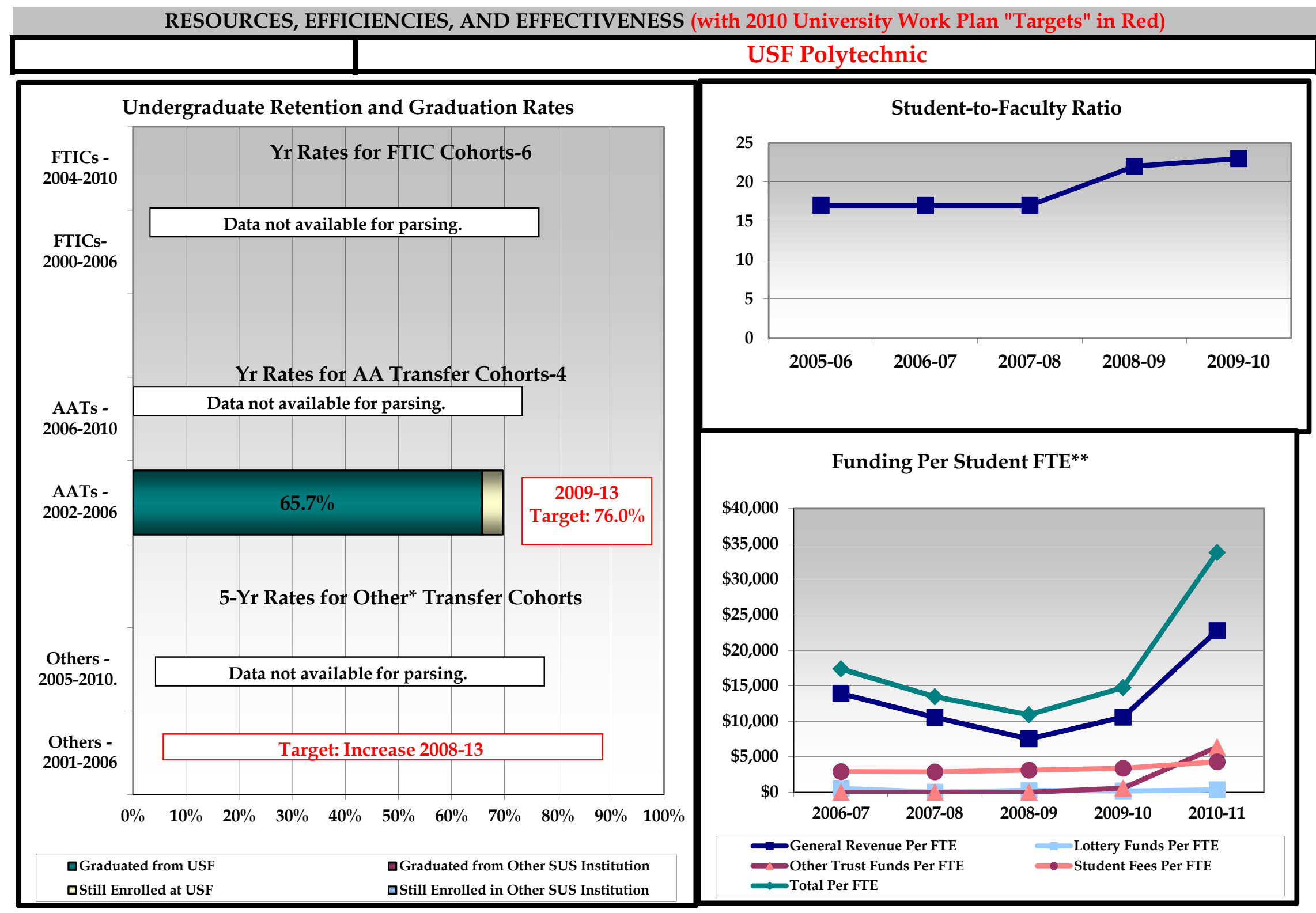

* The composition of "Other Transfer" cohorts may vary greatly by institution and by year.

** FTE for this metric uses the standard IPEDS definition of FTE, equal to 30 credit hours for undergraduates and 24 for graduates.

Graduation Rate from SAME Institution - Projected Institutional Contributions in RED PRINT. 


\section{Key University Achievements}

Note: Limit to one-page. Enter a maximum of three issues per category. Only use 11-point Book Antiqua font.

\section{Student awards/achievements}

1. The Campus Climate Survey indicated that $96 \%$ of 337 of our home campus students feel the quality of academic programs at USF Polytechnic is excellent, and $97.6 \%$ of 337 of our home campus students would recommend USF Polytechnic to their siblings or friends as a good place to go to college.

\section{Faculty awards/achievements}

1. Twenty-two new faculty were hired for AY 2009-2010 from high quality institutions, e.g., Rensselaer Polytechnic Institute, Virginia Polytechnic Institute and State University, Lehigh University, Purdue University, University of Georgia, University of Arizona, University of Pittsburgh, Indiana University, University of Hawaii.

\section{- Program awards/achievements}

1. The M.S. in Information Technology was approved by the USF Board of Trustees with targeted implementation for summer 2011.

\section{Research awards/achievements}

1. Three new University centers were submitted to the USF System President for approval: USF Polytechnic Center for Energy Innovation; USF Polytechnic Blue Sky Center for Incubation Innovation; and USF Polytechnic Center for Policy Analysis, Research \& Evaluation.

2. Three research labs were established: RFID Applications Lab, the Food Quality and Safety Research and Development Lab, and the Applied Neurosciences Lab.

3. The Florida Institute for Phosphate Research was renamed the Florida Institute for Industrial and Phosphate Research and established administratively in USF Polytechnic in the 2009-2010 legislative session.

\section{- Institutional awards/achievements}

1. $\$ 52.5$ million in funding for construction and infrastructure has been secured, with $\$ 35$ million in private support raised by Dr. Marshall Goodman, Campus Executive Officer. 


\section{INTRODUCTION}

\section{University of South Florida, Polytechnic}

\section{Mission}

The University of South Florida Polytechnic is committed to excellence in interdisciplinary and applied learning; to the application of cutting-edge research and technology to real world needs; and to collaborative partnerships that support economic, social, and community development.

http://www.poly.usf.edu/AboutUs/StrategicPlan.html

\section{Vision}

The University of South Florida Polytechnic will be a premier destination campus for applied learning, research and innovative technology. Our students and graduates will inspire and lead change, locally and internationally.

http:// www.poly.usf.edu/ AboutUs/StrategicPlan.html

\section{Context}

Effective July 1, 2008, Florida Statute 1004.345 established The University of South Florida Polytechnic, a separate organizational and budget entity of The University of South Florida, intended to operate under separate accreditation from the Southern Association of Colleges and Schools Commission on Colleges.

As the USF System has evolved, it has dramatically expanded access to Florida residents and highly motivated students from around the world. The diversity of its four campuses will continue to accommodate the development of distinctive models of higher education - what the USF Board of Trustees has described as "mission differentiation" - to serve the current and emerging education, research and economic development needs of the state, nation and world.

The state's economy has historically been driven by agriculture, tourism and real estate. Under Governor Jeb Bush, however, Florida designated its emerging core, anchored by I-4, as “Florida's High
Tech Corridor." The FHTC's establishment has helped to focus those inside and outside the state on the tremendous potential of technology-driven economic development within Florida.

In 2008, the Central Florida Development Council hired SRI International, an independent research firm, to conduct a detailed analysis of the region's current economic strengths and opportunities. The resulting "cluster analysis" study identified seven industry sectors that were already represented in the regional economy and primed for future growth: research and engineering services; logistics and supply chain management; life science and medical services; education and government; construction and real estate; business and financial services; agriculture and agritechnology.

As the region's public and private sectors mobilize to explore and cultivate the industry clusters identified in the SRI International cluster study, USF Polytechnic has aligned the institution's design with its socio-economic context, providing a distinct focus for the development of its new campus on I-4, its colleges and its academic programs.

USF Polytechnic's I-4 campus is being developed as a unique "bioscape," designed by world-renowned architect, Dr. Santiago Calatrava. The campus context will emerge as an unprecedented synthesis of architecture, design, engineering, agriculture and sustainability - a living example of the research, academic and social missions of USF Polytechnic.

The structure of USF Polytechnic's three interdisciplinary colleges reflects its commitment to interdisciplinary and applied learning. The College of Technology and Innovation houses the divisions of Innovation Management, Information Technology, and Engineering and Applied Sciences. The College of Human and Social Sciences includes the divisions of Social Sciences, Education, and Allied Health Sciences. The third college, Applied Arts and New Media, will house Architecture and Design, Technical and Professional Communication, and Digital Arts and New Media. 
While the polytechnic model itself is not new, it is relatively new to the southeastern United States - and thoroughly novel to Florida's public higher education system. Methodologically, polytechnics focus on applied, multi-disciplinary learning and research. Learning environments are created to facilitate hands-on, collaborative problem solving and inquiry. Learning experiences include problem-based applications, field experiences, practica and internships. Rather than basic, theoretical research, polytechnics focus on the practical application of existing knowledge to solve tangible problems and provide tangible social benefits. Rather than reifying the "silo" paradigm so common in American higher education, polytechnics orient scholarship collaboratively in a relentless pursuit of crossdisciplinary synergies and innovation.

Substantively, polytechnics tend to cultivate strengths in the applied scientific and professional fields, such as engineering, sciences, business and education. Traditional "liberal arts" disciplines are not absent from the curriculum but are often delivered within the context of the general education curricula and embedded in the multidisciplinary, applied discovery characteristic of the polytechnic experience.

\section{Developmental and Aspirational Peer Institutions}

USF Polytechnic has selected three developmental peers:

- Arizona State University's Polytechnic Campus in Mesa, AZ, is a public, suburban university established in 1996 as ASU East. In 2005 the campus name and mission were changed to ASU's Polytechnic Campus, serving more than 9,600 students in more than 40 undergraduate and master's degree programs.

- California Polytechnic State University in San Luis Obispo, CA, is a public, suburban university established in 1901. It serves approximately 20,000 students offering numerous polytechnic bachelor's, master's and doctoral degrees.

- The University of Wisconsin Stout Campus in Menomonie, WI, is a public, rural university established in 1971 as a regional campus in the University of Wisconsin System. In 2007 UW-Stout was designated "Wisconsin's Polytechnic University" by the UW
System Board of Regents with a mission as a "comprehensive, career-focused polytechnic where students, faculty and staff use applied learning, scientific theory and research to solve real-world problems, grow the state economy and serve society." UW Stout currently serves 8,800 students offering 50 , primarily undergraduate and master, degrees.

Two aspirational peers have also been selected:

- Rensselaer Polytechnic Institute in Troy, NY is a private, urban university established in 1824. It serves approximately 7,300 students offering bachelor's, master's and doctoral degrees in many of the science, technology, engineering, and mathematic areas.

- Virginia Tech in Blacksburg, VA is a public, rural university established in 1872. It serves approximately 30,000 students with a strong emphasis on polytechnic bachelor's, master's and doctoral degrees.

\section{BOARD OF GOVERNORS - STATE UNIVERSITY SYSTEM GOAL 1: ACCESS TO AND PRODUCTION OF DEGREES}

In AY 2009-2010 total undergraduate FTE (lower and upper levels) increased by $3.6 \%$ from 778 to 806 . Grad I FTE decreased by $21.8 \%$ from 133 to 104 during the same period.

The percentage of undergraduate students who applied for admission to USF Polytechnic, were accepted and then enrolled in courses increased from $74 \%$ to $75 \%$. The percentage of graduate students who applied for admission to USF Polytechnic, were accepted and then enrolled in courses increased from $74 \%$ to $75 \%$.

The number of bachelor's degrees awarded in the same time period decreased from 299 to 254 . The time to degree increased from 2.66 years to 2.91 years. The average undergraduate GPA decreased from 3.05 to 2.99 . The number of master's degrees awarded decreased from 
103 to 78 . The time to degree increased from 1.64 years to 1.72 years. The average graduate GPA decreased from 3.82 to 3.78 .

In AY 2009-2010, the following strategies to increase student enrollment and retention were implemented:

- Establishment of an Enrollment Management unit and increased staffing in admissions, recruitment and advising. Development and monitoring of a comprehensive enrollment management plan for marketing, recruitment, admissions, advising, retention and graduation of diverse and high quality students.

- Increased comprehensive student life activities to include academic and technology extra- and co-curricular activities; social and community engagement opportunities; and personal, academic and career support services.

- Increased opportunities for student leadership, mentoring and learning community programs to contribute to student success and create a sense of belonging to USF Polytechnic.

- Implementation of Hobson's Communication Management System to enhance student progress to degree and retention. Approval by the USF Polytechnic Campus Board, the USF Board of Trustees, and the Board of Governors for lower-division enrollment was obtained in September 2009. An update to the USF Polytechnic Strategic Plan 2007-2012 was presented to the USF Board of Trustees in October 2009 and approved. To realize its vision of being a destination campus, USF Polytechnic plans to pilot a freshman cohort in fall 2012 and prepare for a freshman class in fall 2013. Funding models for campus housing/residence halls are being explored.

A strategy for the development of the General Education core is focusing on a narrow number of course offerings, aligned with the USF Polytechnic Core Values as identified in the 2007-2012 Strategic Plan. This will enable USFP to deliver general education that meets State requirements, demonstrates measurable performance-based competencies, and includes field-based and internship experiences for all students with fewer course offerings. A concurrent strategy for faculty hiring is focusing on addition of faculty in English, mathematics and statistics, natural sciences, life sciences, humanities, communication, political science and international affairs. Staff hiring will continue to target support for Student Affairs and academic program support.

\section{BOARD OF GOVERNORS - STATE UNIVERSITY SYSTEM GOAL 2: MEETING STATEWIDE PROFESSIONAL AND WORKFORCE NEEDS}

USF Polytechnic Extended University hosted three conferences:

- BioFuel: Renewable Fuel Potential for Central Florida - a half day conference in February 2009, assembling, supporting and facilitating discussions among individuals and companies that will be integral to the development of renewable energy sources in Central Florida, from farming, financing and processing to delivery of final product.

- Cold Chain Conference - a three day conference in February 2010 hosting 80 participants from a variety of interrelated fields such as regulatory agencies, academia, suppliers, forwarders, and airlines. Attendees heard presentations and took part in hands-on workshops addressing handling, storage, and distribution issues related to temperature-sensitive pharmaceuticals.

- Diversity Conference - a one day conference in September 2010 on A New World Order: The Impact of Entertainment and Technology on College Students, Their Employers, and Professionalism.

Extended University also delivered professional and personal development programs in Writing Effectively, English Language for Business, Control Systems Certificate, and Nonprofit Management. New programs are being developed in HR Practitioner's Certificate; P.E. Exam Prep; Project Management Certification Prep; Beginning, Intermediate and Advanced AutoCAD Training; Board 491 Clinical Supervision; and a Wellness program. 


\section{BOARD OF GOVERNORS - STATE UNIVERSITY SYSTEM GOAL 3: BUILDING WORLD-CLASS ACADEMIC PROGRAMS AND RESEARCH CAPACITY}

\section{Academic Programs}

In AY 2009-2010 emphasis was increased on internship, practica and field experiences, and service learning opportunities for students, e.g., IT senior projects engaging with local businesses or government agencies; establishment of an IT practicum featuring students working in small teams on practical, real-world problems of value to the campus.

New concentrations in the Bachelor of Science in Applied Science were developed for delivery in AY 2010-2011: Nutrition,

Entrepreneurship, and Supply Chain Management. Additional concentrations are being developed: Health Information Management, Modern Architectural Studies, Sustainable Building Architecture, Global Criminology Studies, and Juvenile Crime.

The Department of Information Technology completed the University approval process for an M.S. in Information Technology degree, targeted for delivery in summer 2011. Undergraduate students with exemplary performance in an advised cluster of courses are awarded a Certificate of Specialization. Two initial certificates have been awarded - Information Security and Web Development. Two new specialized clusters of courses are in development - health informatics and mobile device applications.

The development of new degree programs will be aligned with the polytechnic model and identified economic development industry sectors. Examples of potential future "polytechnic" programs that are in development for delivery 2012-2015, following separate SACS accreditation, are:

- B.A. Digital Arts \& Digital Media

- B.S. Communication Sciences \& Technologies

- B.S. Interdisciplinary Engineering
- B.S. Manufacturing Engineering Technology

- M.S. Manufacturing Engineering

- Pre-Pharmacy Program

- B.S. Medical Technologist

- B.S. Agricultural \& Biological Engineering

- B.A. Architecture

- B.A. Design

- B.S., M.Ed. Integrated STEM Education (Elementary Track, Secondary Track)

- $\quad$ B.S., M.Ed. Technology-Mediated Learning

- B.S. Forensic Science/Studies

\section{Research Capacity}

Three new University centers were submitted to the USF System President for approval:

The USF Polytechnic Center for Energy Innovation conducts research, analyses and education on the engineering, science, infrastructure and socio-economic aspects of biofuels as a sustainable energy economy for Florida. The Center engages a collection of scholars and professionals across disciplines and among Center associates, government agencies, business and industry with the primary goal of developing, broadening, strengthening and sustaining interdisciplinary collaboration, discovery and application.

\section{The USF Polytechnic Blue Sky Center for Incubation Innovation} provides an environment of creativity, imagining, visioning, innovation and essential business resources to nurture new ideas, new technologies and the growth of dynamic new companies.

\section{The USF Polytechnic Center for Policy Analysis, Research \&}

Evaluation (CPARE) engages in public policy analysis and social and behavioral research to inform decision makers and the general public on relevant policy issues. The Center offers rigorous survey development and data collection, using sound methodological sampling and analysis, while maintaining the highest possible ethical standards of conduct. Projects include needs assessments, 
environmental/context studies, opinion surveys, client feedback surveys, social or economic impact studies and political polls.

Information Technology continues to be central to the development of USF Polytechnic. Three research projects at USF Polytechnic illustrate the capacity of information technology as an interdisciplinary driver in the region: the Center for the Development of Information Technology Applications for Manufacturing and Distribution (CITA), Computing Education Research at Lakeland (CEReAL), and Linux Integration Networking Connections (LINCS).

- CITA operated as a partnership between the University of South Florida Polytechnic and the local business/industry community. An interdisciplinary team of USF Polytechnic faculty and staff representing the academic divisions of Information Technology, Engineering and Business/Innovation Management worked with current and emerging regional manufacturing, warehousing and distribution industries to further the development of technology applications, professional development systems and postsecondary programs in the area of Information Technology. The project was funded by a U.S. Small Business Administration Congressional Earmark grant.

- CEReAL is an interdisciplinary research group, actively promoting and conducting research in advanced pedagogical techniques for teaching computing to undergraduates. Its members have been prolific in conference and journal publications, and effective in obtaining federal funding to support their research and the development of infrastructure and Information Technology curricula.

- LINCS is a joint NSF grant (with Polk State College) awarded in 2008 for a three-year term. This project is developing an innovative 4-year online curriculum in Linux System Administration, emphasizing pervasive use of advanced pedagogical methods. The curricular design is dual tracked for both BSIT and AS-BSAS students.
The RFID Applications Lab and the Food Quality and Safety Research and Development Lab were established. The RFID Lab examines applications of RFID technology to supply chain management in food and packaging, and pharmaceutical industries. The Food Quality and Safety Lab examines factors that effect the quality, packaging, distribution and safety of food products.

The Applied Neuroscience Lab was developed and will be established in fall 2010. The lab will enable research using brain mapping technology to examine the factors that stimulate, enhance or inhibit brain function (e.g., the effects of chemotherapy on memory, the response patterns of children with ADHD or bipolar disorders).

The Florida Institute for Phosphate Research was renamed the Florida Institute for Industrial and Phosphate Research and established administratively in USF Polytechnic in the 2009-2010 legislative session. The Florida Institute of Phosphate Research (FIPR) was established in 1978 as an independent state research agency to study phosphate issues that impact Florida's citizens, environment and economy and to serve as a phosphate information resource.

Both USF Polytechnic and FIIPR have common interests in applied learning, research and technology; have joint interests in commercialization of technologies and business incubation; and include areas of interest in environment, public health, technology research, industrial development, education and public information.

\section{BOARD OF GOVERNORS - STATE UNIVERSITY SYSTEM GOAL 4: MEETING COMMUNITY NEEDS AND FULFILLING UNIQUE INSTITUTIONAL RESPONSIBILITIES}

\section{Economic Development}

The USF Polytechnic Blue Sky Center for Incubation Innovation has four components that are intended to enhance regional economic development: 
- The Innovation Station which provides an environment that supports "idea people" to understand what innovation is, how an "innovative idea" develops, where it applies, what risks and costs accompany it, and what relationships and resources are needed to make it real. The Innovation Station provides workshops, study groups, think tank focus groups, expert presentations and consultations, and networking opportunities to help "idea people" to create an innovative concept and determine its viability for research and design.

- The Research Application Lab provides clients with a turnkey package of facilities that enable entrepreneurs to design, develop and test their innovations with coaching and consultation by university faculty and expert consultants.

- The Blue Sky Incubators provide clients with a turnkey package of facilities, full-time staff, business coaches and comprehensive business assistance that helps entrepreneurs develop business concepts, plans and strategies to identify and address growth risks, technology and production risks, marketability and competition risks, financial risks and management, service providers (e.g., lawyers, accountants, strategists, specialized equipment and/or facilities), human capital, strategic alliances/relationships and strategic resources. The Incubator provides an infrastructure for business development and acceleration, technology commercialization, capital identification and acquisition, market entry and competitive advantage.

- The Applied Learning Lab draws on the intellectual capital of faculty, professional staff and consulting experts, the Applied Learning Lab provides comprehensive consulting and training programs for regional businesses and industry, educational institutions, municipalities and non-profit organizations in support of educational, economic and social development efforts in the region and state. The Applied Learning Lab also provides opportunities for university and high school students to connect what they are learning in their college and school classrooms to volunteer, service learning, field experiences and internships, working with Incubator clients and professional staff. Also, through the Student Venture Club, faculty, professional staff and business coaches support student entrepreneurs in developing their innovative ideas, designing and testing their innovations, and competing for start-up grants and internship scholarships to develop their own small business plans.

\section{International Partnerships}

International cooperative partnerships for education and faculty research exchange are also coordinated through Extended University. Partnerships agreements have been developed with the following education institutions and government agencies:

- Avans University of Applied Sciences, the Netherlands, 2010-2015

- Escuela Americana, El Salvador, 2009-2012

- FEPADE - Fundacion Empresarial Para El Desarrollo Educative, El Salvador, 2009-2012

- Grenoble Institute of Technology - ESISAR, France, JuneSeptember 2010

- L'Institute Polytechnique de Grenoble, France, 2010-2015

- Multimedia Incubator Belle de Mai, France, 2010-2013

- University of Nice - Sophia Antipolis, France, 2010-2015

- University of Provence Aix-Marseille, France, 2009-2014

- Turku University of Applied Sciences, Finland, 2009-2012

- Vidyalankar Dnyanapeeth Trust's Vidyalandkar School of Informational Technology, India, 2010-2015

Such partnerships will be helpful as USF Polytechnic addresses its core value for global experiences and vision of being a destination campus. In partnership with USF Tampa, USF Polytechnic will develop a recruitment office in India to attract students to graduate degree programs.

\section{Community Education}

The USF Polytechnic Summer Gifted and Talented Program is coordinated through Extended University. In summer 2010 the program featured three high-tech, high-engagement learning experiences: Hot2Bot, Sci-Fi High and Extreme Green Adventure. 
Sixty-four middle school students attended the program in summer 2009 , with $60 \%$ receiving donor-granted scholarships. In summer 2010 73 middle school students attended the program, with $61 \%$ receiving donor-generated scholarships.

The Rath Senior ConNEXTions and Education Center provides community partnerships, collaboration and education, addressing elder needs and life-long learning. The center provides support for student internships and opportunity for faculty to conduct research at the center. The Rath Center currently facilitates four education and support groups: the Alzheimer's Disease/Dementia Caregiver Support Group, the Beginning Alzheimer's Support and Education (BASE), the Beyond BASE: Mild Cognitive Impairment/Early State Dementia Support and Education Group, and the Parkinson's Disease Support Group. The Senior Scholars Program provides personal development short courses for senior citizens (e.g., Beginning and Intermediate Computers, Healthy Cooking, Life Writing, Brain Fitness, Beginning Spanish, Geneology, Acting for the Stage).

USF Polytechnic's MasterMinds Program is a tutoring program designed for students in grades 1 through 8 who are experiencing reading and/or writing difficulties or who need additional support. Tutoring is conducted in a one-on-one setting focusing on vocabulary, spelling and writing skills. Tutors are master's degree students in Reading Education who also receive mentoring from faculty.

In cooperation with the Polk County Schools District, two new initiatives were established:

- Financial Literacy Training, in collaboration with the Polk County School Board, providing curriculum and training to teach middle and high school students about managing money, planning for college, and general financial planning.

- Promoting Academic Success for Boys of Color Program, using identity-based mentoring principles to increase mentee psychological, social and academic development; sense of belonging; and leadership development through college student mentors supporting elementary students in grades 1-3.

\section{PROGRESS ON PRIMARY INSTITUTIONAL GOALS AND METRICS AS OUTLINED IN THE UNIVERSITY WORK PLAN}

In October 2009 an update on the USF Polytechnic 2007-2012 Strategic Plan was submitted to the USF Board of Trustees and approved, reaffirming the following five goals:

1. Recruit, develop, and retain world-class practitioner scholars with capacity to deliver the polytechnic vision in teaching, research, and community engagement.

2. Recruit students locally, nationally, and internationally who are prepared for a polytechnic learning environment, and provide programs and opportunities that enhance student retention and academic, personal, and professional success.

3. Expand and create academic programs that focus on applied learning, applied research, applied technology, and interdisciplinary approaches in a polytechnic model. Develop and implement new degree programs in five areas of distinction: applied health sciences; mathematics and science education; business and entrepreneurship; manufacturing engineering and technology; and information technology.

4. Implement the Campus Master Plan and develop a campus infrastructure to support a polytechnic learning and research environment, and develop a stable economic base for continued campus and program development as a polytechnic campus.

5. Develop collaborative public and private partnerships that enhance funding opportunities, including leveraging state and federal funding. 


\section{A report on progress for Goals 1 and 4 will be included in this annual report.}

\section{Progress on Goal 1}

Twenty-two new faculty were hired in AY 2009-2010 from high quality institutions, e.g., Rensselaer Polytechnic Institute, Virginia Polytechnic Institute and State University, Lehigh University, Purdue University, University of Georgia, University of Arizona, University of Pittsburgh, Indiana University, University of Hawaii.

A faculty hiring plan for AY 2010-2011 includes 37 new faculty positions in the areas of Communication and New Media, Criminology, Educational Leadership, Elementary Education/ESOL, Elementary Education/Literacy, Experimental Psychology, Industrial Psychology, Biology/Microbiology, Chemistry, Health Informatics, Mathematics, Physics, Marketing, Finance, Statistics, Management, Information Systems, Accounting, Engineering and Information Technology, and Architecture.

\section{Progress on Goal 4}

An updated Campus Master Plan was presented to the USF Board of Trustees in October 2009. The following progress has been made on the implementation of that plan:

- Selected an internationally acclaimed architect.

- Selected a location for the first facility.

- Secured \$52.5 million in funding for construction and infrastructure

Dr. Santiago Calatrava, a product of several polytechnic universities in Europe, was selected as the architect for the new I-4 campus. The first facility will be visible to millions of annual travelers along Interstate 4 . The facility will establish an open, multipurpose design in support of the interdisciplinary and collaborative learning environment foundational to a polytechnic experience for our students. It will also focus on sustainability and synergy with the natural environment.
The site for the campus is currently a green field site with no existing amenities including access to the site and infrastructure (including internal roads, water, electricity, sewers, waste removal, etc.).

Construction for infrastructure began in late spring 2010 while Phase I facilities are in design. Construction of Phase I facilities will begin in fall 2011 with a 23-month construction period anticipated, projecting occupancy in summer 2013.

Public and private partners have demonstrated phenomenal support for the development of the new campus:

- Polk County Investment $\$ 11.7$ million. Polk County officials identified the need to reach the site from the East, seeing value in combining efforts with the University by creating synergistic sports opportunities in the county's Lake Myrtle complex and linking them to the campus site (less than 2 miles away). To that end Polk County designed and constructed a four-lane access from Berkeley Road to the Polk Parkway, creating a major entrance gateway to the campus from the east.

- State of Florida Turnpike Authority Investment \$31.9 million; Williams Company $\$ 9.4$ million. The Turnpike Authority recognized the need for access to the campus and its surrounding developments via the Polk Parkway. Numerous discussions have taken place over several years resulting in a pledge to create a $\$ 32$ million exit interchange at Pace Road from the Polk Parkway. This commitment, along with a project to four-lane the Polk Parkway from Interstate 4 to the Pace Road interchange, resulted in a partnership that included a pledge from the Williams Company toward the project. The project is currently under construction with anticipated completion in December 2011.

- Florida Department of Transportation Investment \$28 million. While the Pace Road and Turnpike projects yielded access to the site from the east, the more pressing concerns from the local host community revolved around access to the property from the west for life-safety responses as well as for access for the largest concentration of constituents for the campus. The Florida Department of 
Transportation, in concert with the City of Lakeland and the Transportation Planning Council of Polk County, identified the East/West Road project (a 6-mile long road connecting State Road 33 from the west with Pace Road on the east) as their Number 1 priority. The project is currently under construction with anticipated completion by December 2011.

- Polk County invested an additional \$10 million toward the university ring road and part of the overall site infrastructure.

- PECO State Funds \$31.2 million (received); an additional \$35 million was anticipated in 2010. Investments from Private Sources \$10.7 million with anticipated FEGC match. These funds will build the first facility on the campus (Phase I), the Science \& Technology Building, as well as a portion of the campus infrastructure.

- PECO request \$5 million (on current CIP listing); Private Investment $\$ 5$ million (pledged over 3 years, first year received) eligible for FECG match. These funds will build the Interdisciplinary Center for Wellness Education and Research, a multi-purpose facility exemplifying the ideal blend of Town and Gown, bringing the general public and the campus community together around wellness issues, education and research.

- Private Investment $\$ 1$ million (received). The interdisciplinary, applied learning and research in a polytechnic environment, brings the prospect of engaging creative, entrepreneurial energies in the evolving high technology arena of Central Florida as well as engaging polytechnic students in related educational experiences (e.g., learning lab practica and internships). The campus Master Plan included the development of a High Tech incubator, and the updated Master Plan includes the development of an applied learning laboratory where students and aspiring entrepreneurs will work together in the development of new ideas and application of established and emerging research to bring about innovation.

\section{ADDITIONAL INFORMATION ON QUALITY, RESOURCES, EFFICIENCIES AND EFFECTIVENESS}

USF System Services. The USF System provides central services through several offices: 1) Audit \& Compliance, 2) Diversity \& Equal Opportunity, 3) General Counsel, 4) Government Relations, and 5) Special Events and Ceremonies. An annual cost allocation for services from these offices is distributed to each campus in the USF System to ensure consistency in implementation of USF System regulations and policies and to avoid duplication of the system-wide central services.

Other USF Tampa offices also provide services to all campuses within the USF System, for example: 1) Enterprise business systems, e.g., FAST, GEMS, FAIR for student, employee and financial data; 2) purchasing and accounting; 3) Research and Innovation for research compliance and grant/contract proposals, awards and management; 3) USF Libraries; 4) Financial Aid; 5) International Affairs; 6) Decision Support; 7) University Advancement; 8) Information Technology; 9) Communications and Marketing. Again, an annual cost allocation for services from these offices is distributed to each campus in the USF System.

Campus-specific Efforts. Over the last four years USF Polytechnic saved approximately $\$ 300,000$ in telecommunication costs with the implementation of a high function, integrated phone system. USF Polytechnic has created additional recurring savings by moving toward convergent networks integrating operational systems (i.e., Video, Voice, Data, Security cameras and keycard access systems) into the infrastructure of the network removing the necessity to have separate cabling and additional equipment for each service. The Campus Executive Officer has raised more than $\$ 35$ million in private support for the campus master plan. 


\section{ADDITIONAL RESOURCES}

Links to the following resources are provided:

- USF Polytechnic Strategic Plan 2007-2012

- USF Polytechnic Voluntary System of Accountability College Portrait of Undergraduate Education

- Common Data Set

- College Navigator

- USF Polytechnic Institutional Research, Effectiveness and Planning 


\section{Section 1 - Financial Resources (including Health-Science Center \& IFAS, if applicable)}

Table 1A. Education and General Revenues

Table 1B. Education and General Expenditures

Table 1C. Funding per Student

Table 1D. Other Budget Entities

Table 1E. Total Revenues and Expenditures

Table 1F. Voluntary Support of Higher Education

Table 1G. Federal Stimulus Dollars (ARRA)

\section{Section 2 - Personnel}

Table 2A. Personnel Headcount

\section{Section 3 - Enrollment \& Space}

Table 3A. University Full-time Enrollment (FTE)

Table 3B. Enrollment by Location

Table 3C. Space Utilization

\section{Section 4 - Undergraduate Education}

Table 4A. Baccalaureate Degree Program Changes in AY 2009-2010

Table 4B. $\quad$ First-Year Persistence Rates

Table 4C. Federal Definition - Undergraduate Progression and Graduation Rates

for Full-time First-time-in-College (FTIC) Students

Table 4D. SUS - Undergraduate Progression and Graduation Rates

for First-time-in-College (FTIC) Students

Table 4E. SUS - Undergraduate Progression and Graduation Rates for AA Transfer Students

Table 4F. $\quad$ SUS - Undergraduate Progression and Graduation Rates

$$
\text { for Other Transfer Students }
$$

Table 4G. Baccalaureate Degrees Awarded

Table 4H. Baccalaureate Degrees Awarded in Areas of Strategic Emphasis

Table 4I. Baccalaureate Degrees Awarded to Underrepresented Groups

Table 4J. Baccalaureate Completion Without Excess Credit Hours

Table 4K. Undergraduate Course Offerings

Table 4L. Faculty Teaching Undergraduates

Table 4M. Undergraduate Instructional Faculty Compensation

Table 4 N. Student/Faculty Ratio

Table 4O. Licensure Pass Rates

Table 4P. Tuition Differential Fee

\section{Section 5 - Graduate Education}

Table 5A. Graduate Degree Programs Changes in AY 2009-2010

Table 5B. Graduate Degrees Awarded

Table 5C. Graduate Degrees Awarded in Areas of Strategic Emphasis

Table 5D. Licensure Pass Rates

\section{Section 6 - Research and Economic Development}

Table 6A. Research and Development

Table 6B. Centers of Excellence

Table 6C. State University Research Commercialization Assistance Grants

Table 6D. 21st Century World Class Scholars Program

\section{Appendix I - Definitions}


STATE UNIVERSITY SYSTEM - 2010 ANNUAL REPORT

Section 1 - Financial Resources

University of South Florida--Polytechnic

Table 1A. University Education and General Revenues

\begin{tabular}{|c|c|c|c|c|c|}
\hline & $\begin{array}{r}2006-07 \\
\text { Actual } \\
\end{array}$ & $\begin{array}{r}2007-08 \\
\text { Actual } \\
\end{array}$ & $\begin{array}{r}2008-09 \\
\text { Actual } \\
\end{array}$ & $\begin{array}{r}2009-10 \\
\text { Actual } \\
\end{array}$ & $\begin{array}{c}2010-11 \\
\text { Estimates }\end{array}$ \\
\hline $\begin{array}{l}\text { Recurring State Funds } \\
\text { (GR \& Lottery) }\end{array}$ & $\$ 11,561,495$ & $\$ 10,053,299$ & $\$ 9,394,081$ & $\$ 13,025,886$ & $\$ 28,956,731$ \\
\hline $\begin{array}{c}\text { Non-Recurring State Funds } \\
\text { (GR \& Lottery) }\end{array}$ & $\$ 53,000$ & $\$ 102,875$ & $\$ 98,300$ & $\$ 59,794$ & $\$ 100,900$ \\
\hline $\begin{array}{c}\text { Tuition } \\
\text { (Resident/Non-Resident) }\end{array}$ & $\$ 2,249,992$ & $\$ 2,743,529$ & $\$ 3,787,462$ & $\$ 3,901,586$ & $\$ 6,013,000$ \\
\hline Tuition Differential Fee & $\$ 0$ & $\$ 0$ & $\$ 0$ & $\$ 144,450$ & $\$ 331,699$ \\
\hline $\begin{array}{c}\text { Other Revenues } \\
\text { (Includes Misc. Fees \& Fines) }\end{array}$ & $\$ 74,724$ & $\$ 3,109$ & $\$ 2,332$ & $\$ 69,210$ & $\$ 59,400$ \\
\hline $\begin{array}{c}\text { Phosphate Research } \\
\text { Trust Fund }\end{array}$ & $\$ 0$ & $\$ 0$ & $\$ 0$ & $\$ 0$ & $\$ 7,312,164$ \\
\hline Federal Stimulus Funds & $\$ 0$ & $\$ 0$ & $\$ 0$ & $\$ 708,656$ & $\$ 678,080$ \\
\hline TOTAL & $\$ 13,939,211$ & $\$ 12,902,812$ & $\$ 13,282,175$ & $\$ 17,909,582$ & $\$ 43,451,974$ \\
\hline
\end{tabular}

*Note: 2010-11 estimates for the USF System report are accepted at the request of the BOG. It should be noted however, that a discrepancy in the amount of transfers between the main campus and HSC is reflected in this table and in the HSC corresponding table. In turn, the individual campus reports will not roll up to these reflected totals and will corrections will be reflected in the 2011 Annual Report.

\begin{tabular}{|c|c|c|c|c|c|}
\hline & $\begin{array}{r}\text { 2006-07 } \\
\text { Actual }\end{array}$ & $\begin{array}{r}\text { 2007-08 } \\
\text { Actual }\end{array}$ & $\begin{array}{r}\text { 2008-09 } \\
\text { Actual }\end{array}$ & $\begin{array}{r}\text { 2009-10 } \\
\text { Actual }\end{array}$ & $\begin{array}{c}\text { 2010-11 } \\
\text { Estimates }\end{array}$ \\
\hline Instruction/Research & $\$ 8,859,479$ & $\$ 9,420,645$ & $\$ 7,041,399$ & $\$ 7,872,850$ & $\$ 21,258,016$ \\
\hline Institutes and Research Centers & $\$ 0$ & $\$ 0$ & $\$ 0$ & $\$ 0$ & $\$ 0$ \\
\hline PO\&M & $\$ 302,130$ & $\$ 187,904$ & $\$ 156,064$ & $\$ 180,911$ & $\$ 108,790$ \\
\hline $\begin{array}{c}\text { Administration } \\
\text { and Support Services }\end{array}$ & $\$ 1,289,783$ & $\$ 1,444,066$ & $\$ 2,309,412$ & $\$ 2,150,419$ & $\$ 12,595,094$ \\
\hline Radio/TV & $\$ 0$ & $\$ 0$ & $\$ 0$ & $\$ 0$ & $\$ 0$ \\
\hline Library/Audio Visual & $\$ 209,905$ & $\$ 237,544$ & $\$ 415,527$ & $\$ 529,480$ & $\$ 466,617$ \\
\hline Museums and Galleries & $\$ 0$ & $\$ 0$ & $\$ 0$ & $\$ 0$ & $\$ 0$ \\
\hline Agricultural Extension & $\$ 0$ & $\$ 0$ & $\$ 0$ & $\$ 0$ & $\$ 0$ \\
\hline Allied Clinics & $\$ 0$ & $\$ 0$ & $\$ 0$ & $\$ 0$ & $\$ 0$ \\
\hline Student Services & $\$ 697,090$ & $\$ 779,724$ & $\$ 755,885$ & $\$ 805,268$ & $\$ 710,115$ \\
\hline Intercollegiate Athletics & $\$ 0$ & $\$ 0$ & $\$ 0$ & $\$ 0$ & $\$ 0$ \\
\hline TOTAL & $\$ 11,358,387$ & $\$ 12,069,883$ & $\$ 10,678,287$ & $\$ 11,538,928$ & $\$ 35,138,632$ \\
\hline
\end{tabular}


The table reports the actual and estimated amount of expenditures from revenues appropriated by the legislature for each fiscal year. The expenditures are classified by Program Component (i.e., Instruction/ Research, PO\&M,

Administration, etc...) for activities directly related to instruction, research and public service. The table does not include expenditures classified as non-operating expenditures (i.e., to service asset-related debts), and therefore excludes a small portion of the amount appropriated each year by the legislature. Also, the table does not include expenditures from funds carried forward from previous years. 
STATE UNIVERSITY SYSTEM - 2010 ANNUAL REPORT

Section 1 - Financial Resources

University of South Florida--Polytechnic

Table 1C. Funding per Full-Time Equivalent (FTE) Student

\begin{tabular}{|c|c|c|c|c|c|}
\hline & $2006-07$ & $2007-08$ & $2008-09$ & $2009-10$ & $2010-11$ \\
\hline \multicolumn{5}{|c|}{ Appropriated Funding per FTE } \\
\hline General Revenue per FTE & $\$ 13,921$ & $\$ 10,554$ & $\$ 7,530$ & $\$ 10,581$ & $\$ 22,767$ \\
\hline Lottery Funds per FTE & $\$ 561$ & $\$ 36$ & $\$ 276$ & $\$ 189$ & $\$ 350$ \\
\hline $\begin{array}{c}\text { Tuition \& Fees per FTE } \\
\text { (based on Budget Authority) }\end{array}$ & $\$ 2,899$ & $\$ 2,864$ & $\$ 3,117$ & $\$ 3,387$ & $\$ 4,298$ \\
\hline $\begin{array}{c}\text { Other Trust Funds per FTE } \\
\text { Total per FTE }\end{array}$ & $\$ 0$ & $\$ 0$ & $\$ 0$ & $\$ 583$ & $\$ 6,357$ \\
\hline Actual Funding per FTE & $\mathbf{2 0 0 6 - 0 7}$ & $\mathbf{2 0 0 7 - 0 8}$ & $\mathbf{2 0 0 8 - 0 9}$ & $\mathbf{2 0 0 9 - 1 0}$ & est. 2010-11 \\
\hline $\begin{array}{c}\text { Tuition \& Fees per FTE } \\
\text { based on Actual Collections) }\end{array}$ & $\$ 2,899$ & $\$ 2,864$ & $\$ 3,117$ & $\$ 3,387$ & $\$ 5,095$ \\
\hline \begin{tabular}{c} 
Actual Total per FTE \\
\hline
\end{tabular} & $\$ 17,381$ & $\$ 13,454$ & $\$ 10,923$ & $\$ 14,740$ & $\$ 34,569$ \\
\hline
\end{tabular}

*Note: Change to reporting of these data on funding per student FTE may result in differences in years prior to 200910 as history was not modified to reflect the new reporting methodology.

***-Note: Figures are approved for the 2010 Annual Report but it should be noted however,discrepancies due to transfers not reflected in this report may result; figures will be corrected in the following annual report.

Notes: (1) FTE is based on actual FTE, not funded FTE; (2) Does not include Health-Science Center funds or FTE; (3) FTE for these metrics uses the standard IPEDS definition of FTE, equal to 30 credit hours for undergraduates and 24 for graduates; and (4) Actual funding per student is based on actual tuition and E\&G fees (does not include local fees) collected.

\section{Table 1D. University Other Budget Entities}

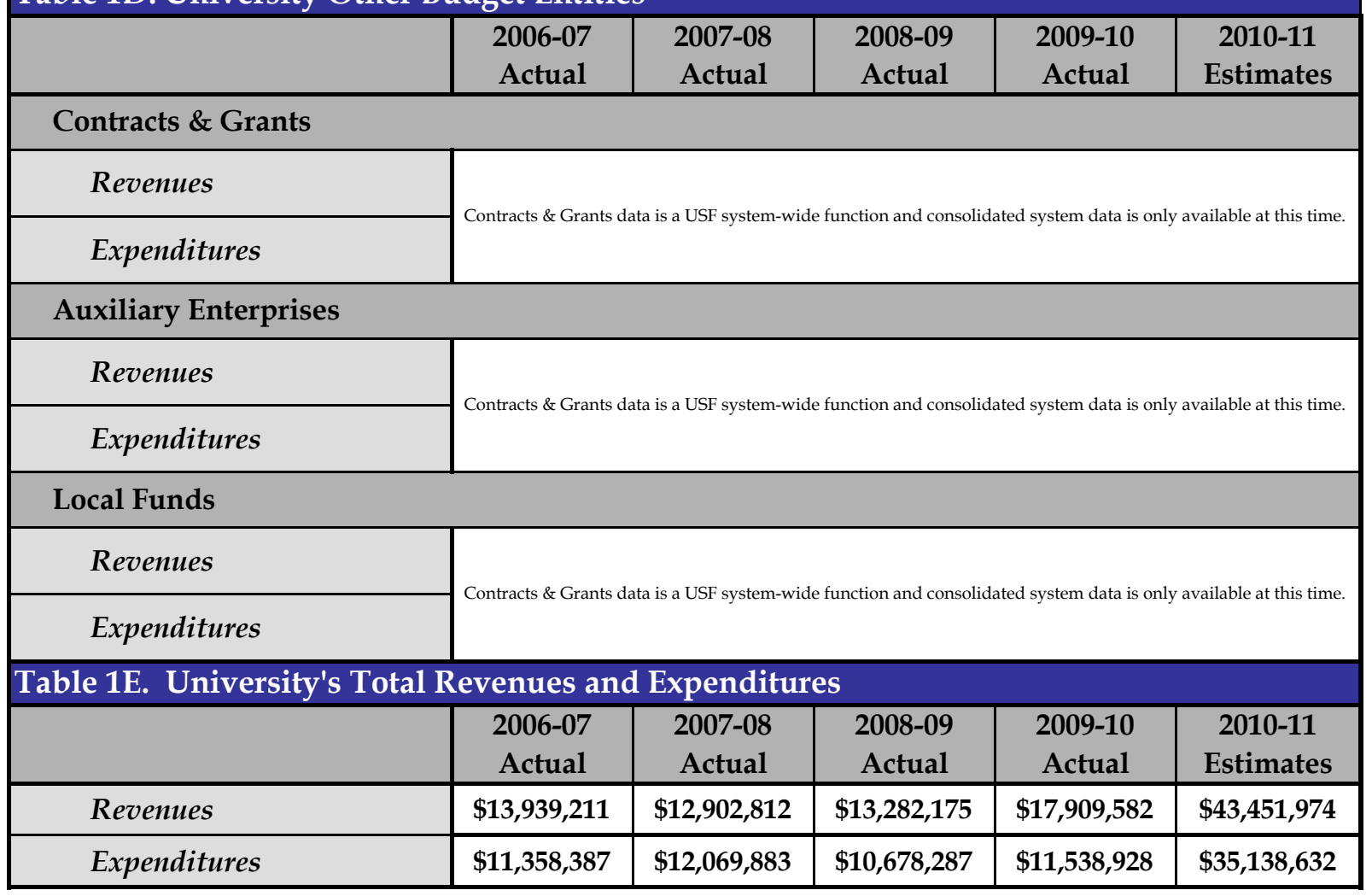


*Note: 2010-11 estimates for the USF System report are accepted at the request of the BOG. It should be noted however, that a discrepancy in the amount of transfers between the main campus and HSC is reflected in this table and in the HSC corresponding table. In turn, the individual campus reports will not roll up to these reflected totals and will corrections will be reflected in the 2011 Annual Report. 
STATE UNIVERSITY SYSTEM - 2010 ANNUAL REPORT

Section 1 - Financial Resources

University of South Florida--Polytechnic

\section{Table 1F. Voluntary Support of Higher Education}

\begin{tabular}{|c|c|c|c|c|c|}
\hline & 2004-2005 & 2005-2006 & 2006-2007 & $2007-2008$ & 2008-2009 \\
\hline $\begin{array}{l}\text { Endowment Market Value } \\
\text { (Thousand \$) }\end{array}$ & \multirow{3}{*}{\multicolumn{5}{|c|}{$\begin{array}{l}\text { Development/Research data is a USF system-wide function. } \\
\text { Consolidated system data is only available at this time. }\end{array}$}} \\
\hline $\begin{array}{l}\text { Annual Gifts Received } \\
\qquad(\$)\end{array}$ & & & & & \\
\hline $\begin{array}{l}\text { Percentage of Graduates Who } \\
\text { Are Alumni Donors }\end{array}$ & & & & & \\
\hline
\end{tabular}

\begin{tabular}{|l|c|c|}
\hline Table 1G. University Federal Stimulus Dollars (ARRA) \\
\hline Proposed Operating Budget Detail & Actual 2009-10 & Proposed 2010-11 \\
\hline Jobs Saved/Created & & $\$ 678,080$ \\
\hline Scholarships & $\$ 08,656$ & $\$ 0$ \\
\hline Library Resources & $\$ 0$ & $\$ 0$ \\
\hline Building Repairs/Alterations & $\$ 0$ & $\$ 0$ \\
\hline Motor Vehicles & $\$ 0$ & $\$ 0$ \\
\hline Printing & $\$ 0$ & $\$ 0$ \\
\hline Furniture \& Equipment & $\$ 0$ & $\$ 0$ \\
\hline Information Technology Equipment & $\$ 0$ & $\$ 0$ \\
\hline Financial Aid to Medical Students & $\$ 0$ & $\$ 0$ \\
\hline Other: & $\$ 0$ & $\$ 0$ \\
\hline TOTAL & $\$ 708,656$ & $\$ 678,080$ \\
\hline
\end{tabular}


STATE UNIVERSITY SYSTEM - 2010 ANNUAL REPORT

Section 2 - Personnel

\section{University of South Florida--Polytechnic}

\section{Table 2A. Personnel Headcount}

\begin{tabular}{|c|c|c|c|c|c|c|c|c|c|c|}
\hline & Fal & 005 & & 006 & & 007 & & 008 & & 009 \\
\hline & FT & PT & FT & PT & FT & PT & FT & PT & FT & PT \\
\hline $\begin{array}{c}\text { Faculty } \\
\text { Tenure/ Tenure-track }\end{array}$ & 22 & 0 & 22 & 0 & 23 & 0 & 19 & 0 & 19 & 0 \\
\hline $\begin{array}{c}\text { Faculty } \\
\text { Non-Tenure Track }\end{array}$ & 10 & 3 & 13 & 3 & 14 & 2 & 12 & 6 & 11 & 5 \\
\hline $\begin{array}{l}\text { Instructors Without } \\
\text { Faculty Status }\end{array}$ & 0 & 0 & 0 & 0 & 0 & 0 & 0 & 0 & 0 & 0 \\
\hline $\begin{array}{c}\text { Graduate Assistants/ } \\
\text { Associates }\end{array}$ & & 7 & & 5 & & 4 & & 2 & & 3 \\
\hline $\begin{array}{c}\text { Executive/ } \\
\text { Administrative/ Managerial }\end{array}$ & 16 & 0 & 17 & 0 & 22 & 0 & 18 & 0 & 18 & 0 \\
\hline Other Professional & 25 & 0 & 24 & 1 & 25 & 0 & 18 & 0 & 21 & 8 \\
\hline Non-Professional & 18 & 0 & 15 & 0 & 20 & 0 & 21 & 0 & 19 & 33 \\
\hline TOTAL PERSONNEL & & & & & & & & & & \\
\hline
\end{tabular}


STATE UNIVERSITY SYSTEM - 2010 ANNUAL REPORT

Section 3 - Enrollment \& Space

University of South Florida--Polytechnic

Table 3A. University Full-Time Enrollment (FTE)

\begin{tabular}{|c|c|c|c|c|c|c|}
\hline \multirow{2}{*}{} & \multicolumn{2}{|c|}{$2008-09$} & \multicolumn{2}{c|}{$2009-10$} & \multicolumn{2}{c|}{$2010-11$} \\
\cline { 2 - 7 } & Funded & Actual & Funded & Actual & Funded & Estimated \\
\hline Florida Residents & 0 & 22 & 0 & 51 & 0 & 53 \\
\hline Lower & 494 & 748 & 494 & 747 & 494 & 761 \\
\hline Upper & 103 & 132 & 103 & 105 & 103 & 119 \\
\hline Grad I & 0 & 1 & 0 & 0 & 0 & 0 \\
\hline Grad II & $\mathbf{5 9 7}$ & $\mathbf{9 0 2}$ & $\mathbf{5 9 7}$ & $\mathbf{9 0 4}$ & $\mathbf{5 9 7}$ & $\mathbf{9 3 3}$ \\
\hline Total & & & & & &
\end{tabular}

Non-Residents

\begin{tabular}{|l|l|l|l|l|l|l|}
\hline Lower & & 0 & & 1 & & 0 \\
\hline Upper & & 9 & & 7 & & 9 \\
\hline Grad I & & 1 & & 0 & & 1 \\
\hline Grad II & & 0 & & 0 & & 0 \\
\hline Total & & $\mathbf{1 1}$ & & $\mathbf{8}$ & & $\mathbf{1 0}$ \\
\hline
\end{tabular}

Total FTE

\begin{tabular}{|c|c|c|c|c|c|c|}
\hline Lower & & 22 & & 52 & & 53 \\
\hline Upper & & 757 & & 754 & & 770 \\
\hline Grad I & & 133 & & 105 & & 120 \\
\hline Grad II & 1 & & 0 & & 0 \\
\hline $\begin{array}{c}\text { Total FTE } \\
\text { (FL Definition) }\end{array}$ & $\mathbf{6 0 6}$ & $\mathbf{9 1 3}$ & $\mathbf{5 9 7}$ & $\mathbf{9 1 2}$ & $\mathbf{5 9 7}$ & $\mathbf{9 4 3}$ \\
\hline $\begin{array}{c}\text { Total FTE } \\
\text { (US Definition) }\end{array}$ & $\mathbf{8 2 2}$ & $\mathbf{1 , 2 1 7}$ & $\mathbf{8 2 2}$ & $\mathbf{1 , 2 1 5}$ & $\mathbf{8 2 2}$ & $\mathbf{1 , 2 5 7}$ \\
\hline
\end{tabular}

Student Headcount in Medical Doctorate (Medicine, Dentistry, Veterinary) Programs

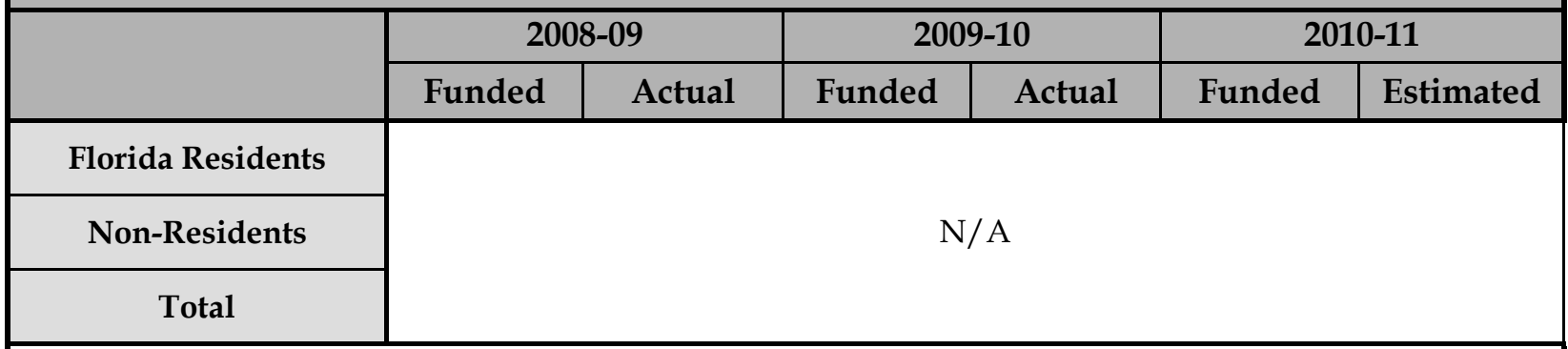

Notes: Florida definitions of FTE (Undergraduate FTE $=40$ and Graduate FTE $=32$ credit hours per FTE) are used for all items except the row named Total FTE (US Definition), which is based on

an Undergraduate FTE $=30$ and Graduate FTE $=24$ credit hours. Actual Medical headcounts are based on Fall enrollment data. 
STATE UNIVERSITY SYSTEM - 2010 ANNUAL REPORT

Section 3 - Enrollment \& Space

\section{University of South Florida--Polytechnic}

\section{Table 3B. Enrollment by Location}

For each distinct location (main, branch, site, regional campus) with> 150 FTE. Add additional tables for sites, as needed.

SITE: USF Polytechnic

\begin{tabular}{|c|c|c|c|}
\hline FTE by LEVEL & $\begin{array}{c}\mathbf{2 0 0 8 - 0 9} \\
\text { Actual }\end{array}$ & $\begin{array}{c}\mathbf{2 0 0 9 - 1 0} \\
\text { Actual }\end{array}$ & $\begin{array}{c}\mathbf{2 0 1 0 - 1 1} \\
\text { Estimated }\end{array}$ \\
\hline Lower & 22 & 52 & 53 \\
\hline Upper & 757 & 754 & 770 \\
\hline Grad I & 133 & 104 & 120 \\
\hline Grad II & 1 & 1 & 0 \\
\hline Total & 913 & $\mathbf{9 1 1}$ & $\mathbf{9 4 3}$ \\
\hline
\end{tabular}

*These figures match the enrollment plan submitted earlier this year. 
STATE UNIVERSITY SYSTEM - 2010 ANNUAL REPORT

Section 4 - Undergraduate Education

University of South Florida--Polytechnic

Table 4A. Baccalaureate Degree Program Changes in AY 2009-2010

\begin{tabular}{|c|c|c|c|c|c|}
\hline $\begin{array}{c}\text { Title of Program } \\
\text { (add more rows as needed) }\end{array}$ & $\begin{array}{c}\text { Six-digit } \\
\text { CIP Code }\end{array}$ & $\begin{array}{c}\text { Degree } \\
\text { Level }\end{array}$ & $\begin{array}{c}\text { Date of } \\
\text { UBOT } \\
\text { Action }\end{array}$ & $\begin{array}{c}\text { Starting } \\
\text { or Ending } \\
\text { Term }\end{array}$ & Comments \\
\hline
\end{tabular}

New Programs

\begin{tabular}{|l|l|l|l|l|} 
N/A & & & & \\
\hline
\end{tabular}

Terminated Programs

\begin{tabular}{|l|l|l|l|l|l|}
\hline N/A & & & & & \\
\hline & & & & & \\
\hline
\end{tabular}

Suspended Programs

\begin{tabular}{|l|l|l|l|l|l|}
\hline N/A & & & & & \\
\hline & & & & & \\
\hline
\end{tabular}

New Programs Considered by University But Not Approved 


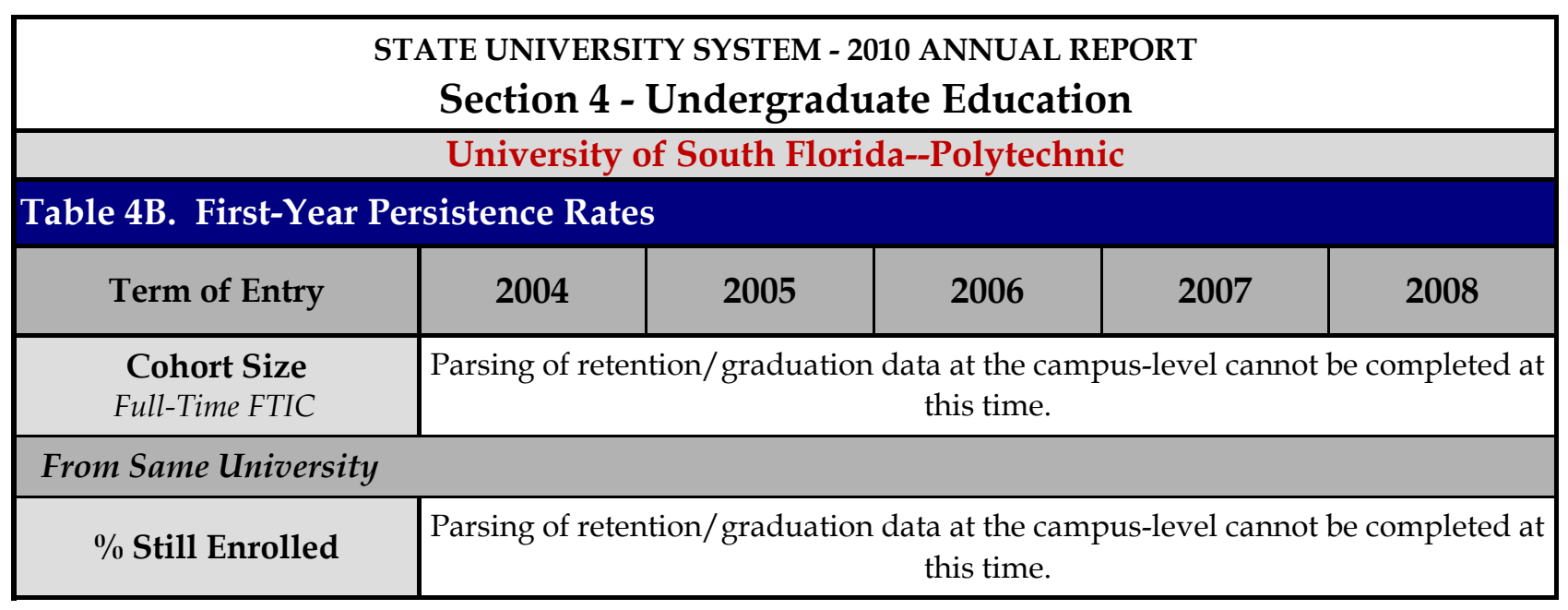

\begin{tabular}{|c|c|c|c|c|c|}
\hline Term of Entry & Fall 2000 & Fall 2001 & Fall 2002 & Fall 2003 & Fall 2004 \\
\hline $\begin{array}{l}\text { Cohort Size } \\
\text { Full-Time FTIC }\end{array}$ & \multicolumn{5}{|c|}{$\begin{array}{l}\text { Parsing of retention/graduation data at the campus-level cannot be completed at } \\
\text { this time. }\end{array}$} \\
\hline \multicolumn{6}{|l|}{6 - Year Rates } \\
\hline \multicolumn{6}{|c|}{ From Same University } \\
\hline$\%$ Graduated & \multirow{2}{*}{\multicolumn{5}{|c|}{$\begin{array}{l}\text { Parsing of retention/graduation data at the campus-level cannot be completed at } \\
\text { this time. }\end{array}$}} \\
\hline \% Still Enrolled & & & & & \\
\hline Success Rate & \multicolumn{5}{|c|}{$\begin{array}{l}\text { Parsing of retention/graduation data at the campus-level cannot be completed at } \\
\text { this time. }\end{array}$} \\
\hline \multicolumn{6}{|c|}{$\begin{array}{l}\text { Notes: (1) Cohorts are based on undergraduate students who enter the institution in the Fall term (or Summer } \\
\text { term and continue into the Fall term); (2) Success Rate measures the percentage of an intial cohort of students } \\
\text { who have either graduated or are still enrolled. }\end{array}$} \\
\hline
\end{tabular}




\section{STATE UNIVERSITY SYSTEM - 2010 ANNUAL REPORT \\ Section 4 - Undergraduate Education Data \\ University of South Florida--Polytechnic}

\section{Table 4D. SUS - Undergraduate Progression and Graduation Rates for First-Time-in-College (FTIC) Students}

\begin{tabular}{|c|c|c|c|c|c|}
\hline Term of Entry & Fall 2000 & Fall 2001 & Fall 2002 & Fall 2003 & Fall 2004 \\
\hline $\begin{array}{l}\text { Cohort Size } \\
\text { Full- E Part-Time }\end{array}$ & \multicolumn{5}{|c|}{$\begin{array}{l}\text { Parsing of retention/graduation data at the campus-level cannot be completed at } \\
\text { this time. }\end{array}$} \\
\hline \multicolumn{6}{|l|}{4 - Year Rates } \\
\hline \multicolumn{6}{|c|}{ From Same University } \\
\hline$\%$ Graduated & \multirow{2}{*}{\multicolumn{5}{|c|}{$\begin{array}{l}\text { Parsing of retention/graduation data at the campus-level cannot be completed at } \\
\text { this time. }\end{array}$}} \\
\hline \% Still Enrolled & & & & & \\
\hline \multicolumn{6}{|c|}{ From Other SUS Institution } \\
\hline$\%$ Graduated & \multirow{2}{*}{\multicolumn{5}{|c|}{$\begin{array}{l}\text { Parsing of retention/graduation data at the campus-level cannot be completed at } \\
\text { this time. }\end{array}$}} \\
\hline$\%$ Still Enrolled & & & & & \\
\hline \multicolumn{6}{|c|}{ From State University System } \\
\hline$\%$ Graduated & \multirow{3}{*}{\multicolumn{5}{|c|}{$\begin{array}{l}\text { Parsing of retention/graduation data at the campus-level cannot be completed at } \\
\text { this time. }\end{array}$}} \\
\hline \% Still Enrolled & & & & & \\
\hline Success Rate & & & & & \\
\hline \multicolumn{6}{|l|}{6 - Year Rates } \\
\hline \multicolumn{6}{|c|}{ From Same University } \\
\hline$\%$ Graduated & \multirow{2}{*}{\multicolumn{5}{|c|}{$\begin{array}{l}\text { Parsing of retention/graduation data at the campus-level cannot be completed at } \\
\text { this time. }\end{array}$}} \\
\hline \% Still Enrolled & & & & & \\
\hline \multicolumn{6}{|c|}{ From Other SUS Institution } \\
\hline$\%$ Graduated & \multirow{2}{*}{\multicolumn{5}{|c|}{$\begin{array}{l}\text { Parsing of retention/graduation data at the campus-level cannot be completed at } \\
\text { this time. }\end{array}$}} \\
\hline \% Still Enrolled & & & & & \\
\hline \multicolumn{6}{|c|}{ From State University System } \\
\hline$\%$ Graduated & \multirow{3}{*}{\multicolumn{5}{|c|}{$\begin{array}{l}\text { Parsing of retention/graduation data at the campus-level cannot be completed at } \\
\text { this time. }\end{array}$}} \\
\hline \% Still Enrolled & & & & & \\
\hline Success Rate & & & & & \\
\hline \multicolumn{6}{|c|}{$\begin{array}{l}\text { Notes: (1) Cohorts are based on undergraduate students who enter the institution in the Fall term (or Summer } \\
\text { term and continue into the Fall term); (2) Success Rate measures the percentage of an intial cohort of students } \\
\text { who have either graduated or are still enrolled. }\end{array}$} \\
\hline
\end{tabular}




\section{STATE UNIVERSITY SYSTEM - 2010 ANNUAL REPORT \\ Section 4 - Undergraduate Education Data \\ University of South Florida--Polytechnic}

\section{Table 4E. SUS - Undergraduate Progression and Graduation Rates}

for AA Transfer Students

\begin{tabular}{|c|c|c|c|c|c|}
\hline Term of Entry & Fall 2002 & Fall 2003 & Fall 2004 & Fall 2005 & Fall 2006 \\
\hline $\begin{array}{c}\text { Cohort Size } \\
\text { Full- E Part-Time }\end{array}$ & Parsing of retention/graduation data at the campus-level cannot be completed at \\
this time.
\end{tabular}

\section{2 - Year Rates}

\begin{tabular}{|l|l|}
\hline \multicolumn{2}{|l|}{ From Same University } \\
\hline \% Graduated & Parsing of retention/graduation data at the campus-level cannot be completed at \\
this time.
\end{tabular}

\section{From Other SUS Institution}

\begin{tabular}{|c|c|}
\hline $\begin{array}{c}\text { \% Graduated } \\
\text { \% Still Enrolled }\end{array}$ & Parsing of retention/graduation data at the campus-level cannot be completed at \\
this time.
\end{tabular}

\section{4 - Year Rates}

\section{From Same University}

\begin{tabular}{|l|l|}
\hline$\%$ Graduated & Parsing of retention/graduation data at the campus-level cannot be completed a \\
this time.
\end{tabular}

\section{From Other SUS Institution}

$\%$ Graduated

$\%$ Still Enrolled
Parsing of retention/graduation data at the campus-level cannot be completed at this time.

\section{From State University System}

$\%$ Graduated

$\%$ Still Enrolled

Success Rate
Parsing of retention/graduation data at the campus-level cannot be completed at this time.

Notes: (1) Cohorts are based on undergraduate students who enter the institution in the Fall term (or Summer term and continue into the Fall term); (2) Success Rate measures the percentage of an intial cohort of students who have either graduated or are still enrolled. 


\section{STATE UNIVERSITY SYSTEM - 2010 ANNUAL REPORT \\ Section 4 - Undergraduate Education Data \\ University of South Florida--Polytechnic}

\section{Table 4F. SUS - Undergraduate Progression and Graduation Rates}

for Other Transfer Students

\begin{tabular}{|c|c|c|c|c|c|}
\hline Term of Entry & Fall 2001 & Fall 2002 & Fall 2003 & Fall 2004 & Fall 2005 \\
\hline $\begin{array}{l}\text { Cohort Size } \\
\text { Full- E Part-Time }\end{array}$ & \multicolumn{5}{|c|}{$\begin{array}{c}\text { Parsing of retention/graduation data at the campus-level cannot be completed at } \\
\text { this time. }\end{array}$} \\
\hline \multicolumn{6}{|l|}{5 - Year Rates } \\
\hline \multicolumn{6}{|c|}{ From Same University } \\
\hline$\%$ Graduated & \multirow{2}{*}{\multicolumn{5}{|c|}{$\begin{array}{l}\text { Parsing of retention/graduation data at the campus-level cannot be completed at } \\
\text { this time. }\end{array}$}} \\
\hline$\%$ Still Enrolled & & & & & \\
\hline \multicolumn{6}{|c|}{ From Other SUS Institution } \\
\hline$\%$ Graduated & \multirow{2}{*}{\multicolumn{5}{|c|}{$\begin{array}{c}\text { Parsing of retention/graduation data at the campus-level cannot be completed at } \\
\text { this time. }\end{array}$}} \\
\hline$\%$ Still Enrolled & & & & & \\
\hline \multicolumn{6}{|c|}{ From State University System } \\
\hline$\%$ Graduated & \multirow{3}{*}{\multicolumn{5}{|c|}{$\begin{array}{l}\text { Parsing of retention/graduation data at the campus-level cannot be completed at } \\
\text { this time. }\end{array}$}} \\
\hline \% Still Enrolled & & & & & \\
\hline Success Rate & & & & & \\
\hline \multicolumn{6}{|c|}{$\begin{array}{l}\text { Notes: (1) Cohorts are based on undergraduate students who enter the institution in the Fall term (or Summer } \\
\text { term and continue into the Fall term); (2) Success Rate measures the percentage of an intial cohort of students } \\
\text { who have either graduated or are still enrolled. }\end{array}$} \\
\hline
\end{tabular}

\section{Table 4G. Baccalaureate Degrees Awarded}

\begin{tabular}{|l|c|c|c|c|c|}
\hline & $2005-2006$ & $2006-2007$ & $2007-2008$ & $2008-2009$ & $2009-2010$ \\
\hline Baccalaureate Degrees & 205 & 226 & 233 & 299 & 254 \\
\hline
\end{tabular}

\section{Table 4H. Baccalaureate Degrees Awarded in Areas of Strategic Emphasis}

\begin{tabular}{|c|c|c|c|c|c|}
\hline & $2005-2006$ & $2006-2007$ & $2007-2008$ & 2008-2009 & 2009-2010 \\
\hline Education & 0 & 0 & 0 & 0 & 0 \\
\hline Health Professions & 0 & 2 & 1 & 5 & 1 \\
\hline $\begin{array}{c}\text { Science, Technology, } \\
\text { Engineering, and Math }\end{array}$ & 22 & 17 & 20 & 18 & 22 \\
\hline $\begin{array}{c}\text { Security and } \\
\text { Emergency Services }\end{array}$ & 19 & 9 & 14 & 21 & 20 \\
\hline $\begin{array}{c}\text { Globalization } \\
\text { TOTAL: Areas of } \\
\text { Strategic Emphasis }\end{array}$ & 1 & 1 & 0 & 1 & 1 \\
\hline
\end{tabular}




\section{STATE UNIVERSITY SYSTEM - 2010 ANNUAL REPORT \\ Section 4 - Undergraduate Education Data \\ University of South Florida--Polytechnic}

\section{Table 4I. Baccalaureate Degrees Awarded to Underrepresented Groups}

\begin{tabular}{|c|c|c|c|c|c|}
\hline & 2005-2006 & 2006-2007 & 2007-2008 & $\begin{array}{c}2008-2009 \\
\text { BASELINE YEAR } \\
\end{array}$ & 2009-2010 \\
\hline \multicolumn{6}{|c|}{ Non-Hispanic Black Students } \\
\hline $\begin{array}{c}\text { Number of } \\
\text { Baccalaureate Degrees }\end{array}$ & 17 & 23 & 27 & $\begin{array}{c}35 \\
\text { Increase* }\end{array}$ & 26 \\
\hline $\begin{array}{c}\text { Percentage of All } \\
\text { Baccalaureate Degrees }\end{array}$ & $8.4 \%$ & $10.7 \%$ & $11.5 \%$ & $\begin{array}{c}11.9 \% \\
\text { Maintain* }\end{array}$ & $10.4 \%$ \\
\hline \multicolumn{6}{|l|}{ Hispanic Students } \\
\hline $\begin{array}{c}\text { Number of } \\
\text { Baccalaureate Degrees }\end{array}$ & 21 & 20 & 24 & $\begin{array}{c}28 \\
\text { Increase* }^{*}\end{array}$ & 29 \\
\hline $\begin{array}{c}\text { Percentage of All } \\
\text { Baccalaureate Degrees }\end{array}$ & $10.3 \%$ & $9.3 \%$ & $10.2 \%$ & $\begin{array}{c}9.5 \% \\
\text { Increase }\end{array}$ & $11.6 \%$ \\
\hline \multicolumn{6}{|l|}{ PELL-Grant Recipients } \\
\hline $\begin{array}{c}\text { Number of } \\
\text { Baccalaureate Degrees* }\end{array}$ & 79 & 89 & 92 & $\begin{array}{c}104 \\
\text { Increase* }^{*}\end{array}$ & 97 \\
\hline $\begin{array}{c}\text { Percentage of All } \\
\text { Baccalaureate Degrees }\end{array}$ & $38.9 \%$ & $41.2 \%$ & $40.7 \%$ & $\begin{array}{c}35.4 \% \\
\text { Maintain* }\end{array}$ & $38.1 \%$ \\
\hline \multicolumn{6}{|c|}{$\begin{array}{l}\text { Note: PELL-Grant recipients are defined as those students who have received a PELL-Grant Within } 6 \\
\text { Years of Graduation. This does not include degrees awarded to students whose race/ethnicity code is } \\
\text { missing (or not reported) or for students who are non-resident aliens. }\end{array}$} \\
\hline
\end{tabular}

*Due to methodology changes in this data metric, campus-level figures may not roll up to the system numbers.

\begin{tabular}{|c|c|c|c|c|c|}
\hline Table 4J. Baccalaureate Completion Without Excess Credit Hours \\
\hline & 2005-2006 & 2006-2007 & 2007-2008 & $\mathbf{2 0 0 8 - 2 0 0 9}$ & $\mathbf{2 0 0 9 - 2 0 1 0}$ \\
\hline $\begin{array}{c}\text { \% of Total Baccalaureate } \\
\text { Degrees Awarded Within } \\
\mathbf{1 1 0 \%} \text { of Hours Required } \\
\text { for Degree }\end{array}$ & N/A & N/A & $68.0 \%$ & $66.7 \%$ & $65.7 \%$ \\
\hline
\end{tabular}

\section{Table 4K. Undergraduate Course Offerings}

\begin{tabular}{|c|c|c|c|c|c|}
\hline \multicolumn{2}{|c|}{ Fall 2005 } & Fall 2006 & Fall 2007 & Fall 2008 & Fall 2009 \\
\hline $\begin{array}{c}\text { Number of } \\
\text { Course Sections }\end{array}$ & 106 & 106 & 107 & 85 & 91 \\
\hline $\mathbf{7 9 . 1} \quad$ & $87.7 \%$ & $87.7 \%$ & $73.8 \%$ & $64.7 \%$ & $79.1 \%$ \\
\hline $\begin{array}{c}\text { Fewer than 30 } \\
\text { Students }\end{array}$ & $12.1 \%$ & $12.1 \%$ & $26.2 \%$ & $34.1 \%$ & $20.9 \%$ \\
\hline $\begin{array}{c}\text { 30 to 49 } \\
\text { Students }\end{array}$ & $0.0 \%$ & $0.0 \%$ & $0.0 \%$ & $1.2 \%$ & $0.0 \%$ \\
\hline $\begin{array}{c}\mathbf{5 0} \text { to 99 } \\
\text { Students }\end{array}$ & $0.0 \%$ & $0.0 \%$ & $0.0 \%$ & $0.0 \%$ & $0.0 \%$ \\
\hline $\begin{array}{c}\text { 100 or More } \\
\text { Students }\end{array}$
\end{tabular}




\begin{tabular}{|c|c|c|c|c|c|}
\hline \multicolumn{6}{|c|}{$\begin{array}{l}\text { STATE UNIVERSITY SYSTEM - } 2010 \text { ANNUAL REPORT } \\
\text { Section } 4 \text { - Undergraduate Education Data }\end{array}$} \\
\hline \multicolumn{6}{|c|}{ University of South Florida--Polytechnic } \\
\hline Table 4L. Faculty Te & ig Underg & dates & & & \\
\hline & $2005-2006$ & 2006-2007 & 2007-2008 & 2008-2009 & $2009-2010$ \\
\hline \multicolumn{6}{|c|}{ Percentage of Credit Hours Taught by: } \\
\hline Faculty & $68.6 \%$ & $57.0 \%$ & $43.0 \%$ & $39.5 \%$ & $45.8 \%$ \\
\hline Adjunct Faculty & $25.6 \%$ & $38.2 \%$ & $55.1 \%$ & $59.5 \%$ & $53.2 \%$ \\
\hline Graduate Students & $5.8 \%$ & $4.2 \%$ & $0.1 \%$ & $0.0 \%$ & $0.0 \%$ \\
\hline Other Instructors & $0.0 \%$ & $0.6 \%$ & $1.8 \%$ & $1.0 \%$ & $1.0 \%$ \\
\hline
\end{tabular}

\begin{tabular}{|l|c|c|c|c|c|}
\hline Table 4M. Undergraduate Instructional Faculty Compensation \\
\hline & Fall 2005 & Fall 2006 & Fall 2007 & Fall 2008 & Fall 2009 \\
\hline $\begin{array}{c}\text { Average Salary and } \\
\text { Benefits for Faculty Who } \\
\text { Teach at Least One } \\
\text { Undergraduate Course }\end{array}$ & $\$ 83,509$ & $\$ 89,184$ & $\$ 92,441$ & $\$ 93,108$ & $\$ 96,578$ \\
\hline $\begin{array}{l}\text { Note: The definition of faculty varies for Tables 4L, 4M and 4N. For Undergraduate Instructional Faculty } \\
\text { Compensation, the definition of faculty is based on pay plan 22. }\end{array}$ \\
\hline
\end{tabular}

\begin{tabular}{|c|c|c|c|c|c|}
\hline & $2005-2006$ & 2006-2007 & $2007-2008$ & 2008-2009 & 2009-2010 \\
\hline Student-to-Faculty Ratio & 17 & 17 & 17 & 22 & 23 \\
\hline \multicolumn{6}{|c|}{$\begin{array}{l}\text { Note: The definition of faculty varies for Tables } 4 \mathrm{~L}, 4 \mathrm{M} \text { and } 4 \mathrm{~N} \text {. For Student/Faculty Ratio, the definition of } \\
\text { faculty is consistent with Common Data Set reporting (which counts full-time equivalent instructional faculty } \\
\text { as full-time faculty plus } 1 / 3 \text { part-time faculty). }\end{array}$} \\
\hline
\end{tabular}




\section{STATE UNIVERSITY SYSTEM - 2010 ANNUAL REPORT}

Section 4 - Undergraduate Education Data

University of South Florida--Polytechnic

\section{Table 4O. Professional Licensure Exams - Undergraduate Programs}

\begin{tabular}{|c|c|c|c|c|c|}
\hline & 2005 & 2006 & 2007 & 2008 & 2009 \\
\hline Nursing: National Cou & $\overline{\text { icensu }}$ & nation & tered & & \\
\hline Examinees & & & \multirow{3}{*}{ N/A } & & \\
\hline Pass Rate & & & & & \\
\hline National Benchmark & & & & & \\
\hline
\end{tabular}

\begin{tabular}{|c|c|c|c|}
\hline & 2008-2009 & 2009-2010 & $\begin{array}{l}2010-2011 \\
\text { Projected }\end{array}$ \\
\hline $\begin{array}{l}\text { Total Revenues Generated } \\
\text { By the Tuition Differential }\end{array}$ & -- & $\$ 144,450$ & $\$ 331,699$ \\
\hline $\begin{array}{c}\text { Unduplicated Count of Students } \\
\text { Receiving Financial Aid Award } \\
\text { Funded by Tuition Differential Revenues }\end{array}$ & -- & 60 & \\
\hline $\begin{array}{c}\text { Average Amount of Awards } \\
\text { Funded by Tuition Differential Revenues } \\
\text { (per student receiving an award) }\end{array}$ & -- & $\$ 894$ & \\
\hline Number of Students Eligible for FSAG & -- & 173 & \\
\hline $\begin{array}{l}\text { Number of FSAG-Eligible Students Receiving } \\
\text { a Waiver of the Tuition Differential }\end{array}$ & -- & 0 & \\
\hline $\begin{array}{l}\text { Value of Tuition Differential Waivers } \\
\text { Provided to FSAG-Eligible Students }\end{array}$ & -- & 0 & \\
\hline \multicolumn{4}{|c|}{$\begin{array}{l}\text { Report on the success of the tuition differential in achieving the articulated purpose. } \\
\text { Include an update on any performance measures that were specified in the Board of } \\
\text { Governors-approved tuition differential proposal. }\end{array}$} \\
\hline \multicolumn{4}{|c|}{ The tuition differential aided more students to receive finanical assistance than the minimum State requirement. } \\
\hline \multicolumn{4}{|c|}{$\begin{array}{c}\text { Detailed expenditures of the revenues generated by the tuition differential will be captured in } \\
\text { the Operating Budget submission each August. }\end{array}$} \\
\hline
\end{tabular}


STATE UNIVERSITY SYSTEM - 2010 ANNUAL REPORT

Section 5 - Graduate Education Data

University of South Florida--Polytechnic

Table 5A. GraduateDegree Programs Changes in AY 2009-2010

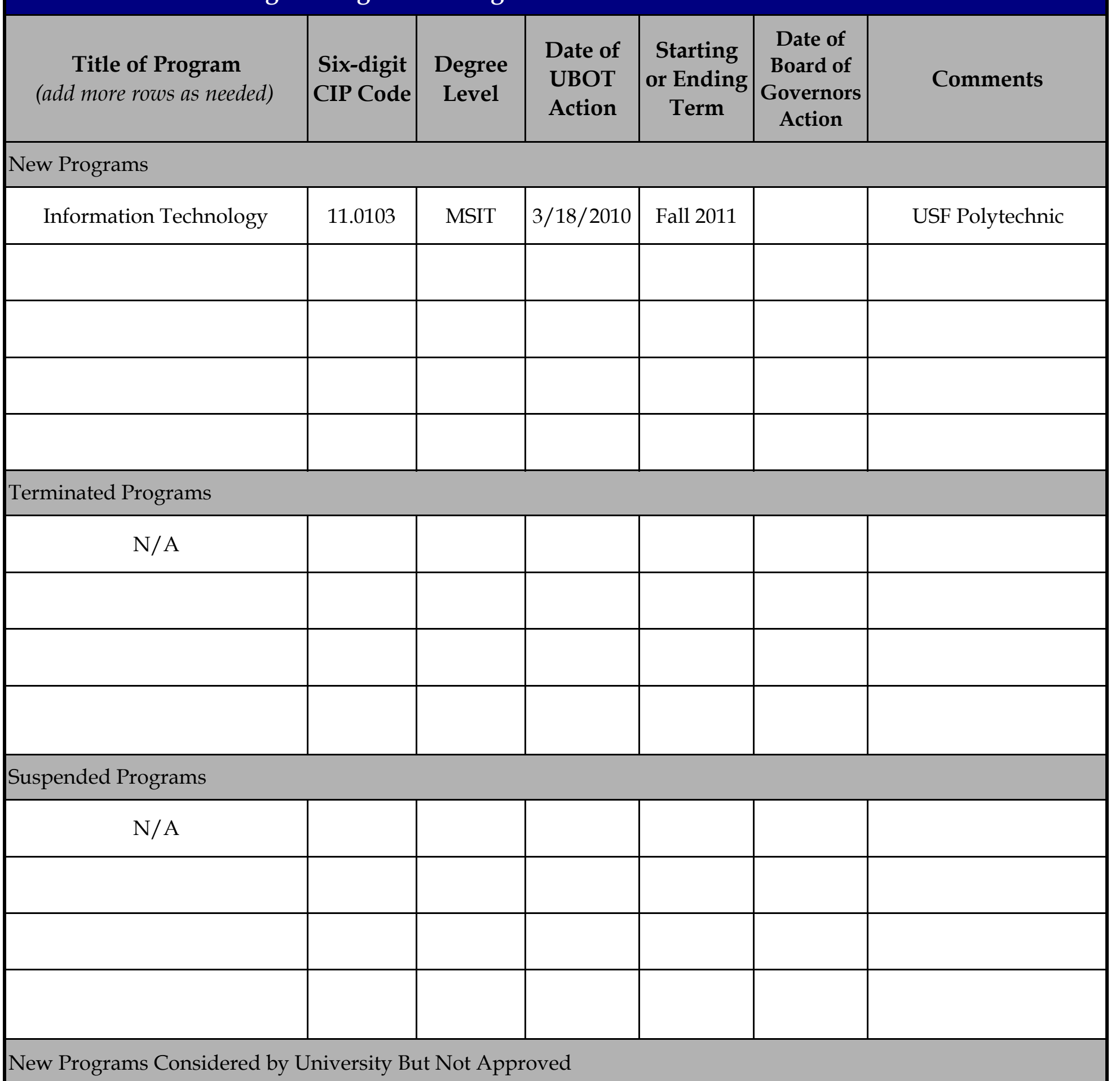

New Programs Considered by University But Not Approved 
STATE UNIVERSITY SYSTEM - 2010 ANNUAL REPORT

Section 5 - Graduate Education Data

University of South Florida--Polytechnic

Table 5B. Graduate Degrees Awarded

\begin{tabular}{|c|c|c|c|c|c|}
\hline & 2005-2006 & 2006-2007 & $2007-2008$ & 2008-2009 & 2009-2010 \\
\hline Master's and Specialist & 46 & 80 & 66 & 103 & 78 \\
\hline Research Doctoral & & & \multirow{6}{*}{ N/A } & & \\
\hline Professional Doctoral & & & & & \\
\hline a) Medicine & & & & & \\
\hline b) Law & & & & & \\
\hline c) Pharmacy & & & & & \\
\hline $\begin{array}{l}\text { Research/ Professional } \\
\text { Doctoral, Combined }\end{array}$ & & & & & \\
\hline
\end{tabular}

Table 5C. Graduate Degrees Awarded in Areas of Strategic Emphasis

\begin{tabular}{|c|c|c|c|c|c|}
\hline & $2005-2006$ & $2006-2007$ & $2007-2008$ & $2008-2009$ & 2009-2010 \\
\hline $\begin{array}{c}\text { Education } \\
\text { Critical Shortage Areas }\end{array}$ & 12 & 19 & 22 & 28 & 11 \\
\hline Health Professions & 0 & 0 & 0 & 2 & 0 \\
\hline $\begin{array}{c}\text { Science, Technology, } \\
\text { Engineering, and Math }\end{array}$ & 3 & 1 & 1 & 0 & 0 \\
\hline $\begin{array}{c}\text { Security and } \\
\text { Emergency Services }\end{array}$ & 0 & 0 & 0 & 0 & 0 \\
\hline Globalization & 0 & 0 & 0 & 0 & 1 \\
\hline TOTAL & $\mathbf{1 5}$ & $\mathbf{2 0}$ & $\mathbf{2 3}$ & $\mathbf{3 0}$ & $\mathbf{1 2}$ \\
\hline
\end{tabular}


STATE UNIVERSITY SYSTEM - 2010 ANNUAL REPORT

Section 5 - Graduate Education Data

University of South Florida--Polytechnic

Table 5D. Professional Licensure Exams - Graduate Programs

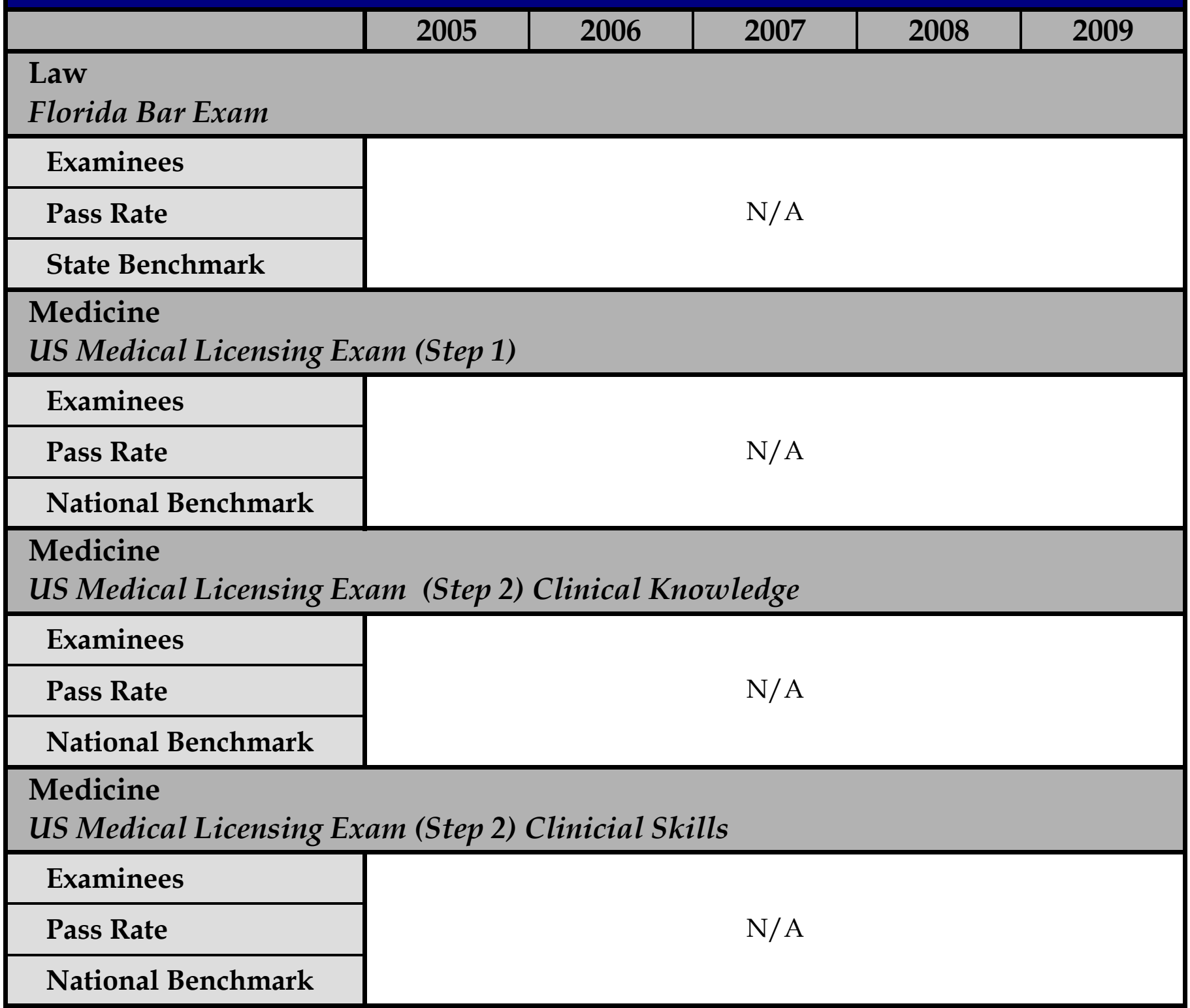

Note: All licensure data is based on first-time examinees. 
STATE UNIVERSITY SYSTEM - 2010 ANNUAL REPORT

Section 5 - Graduate Education Data

University of South Florida--Polytechnic

Table 5D. Professional Licensure Exams - Graduate Programs

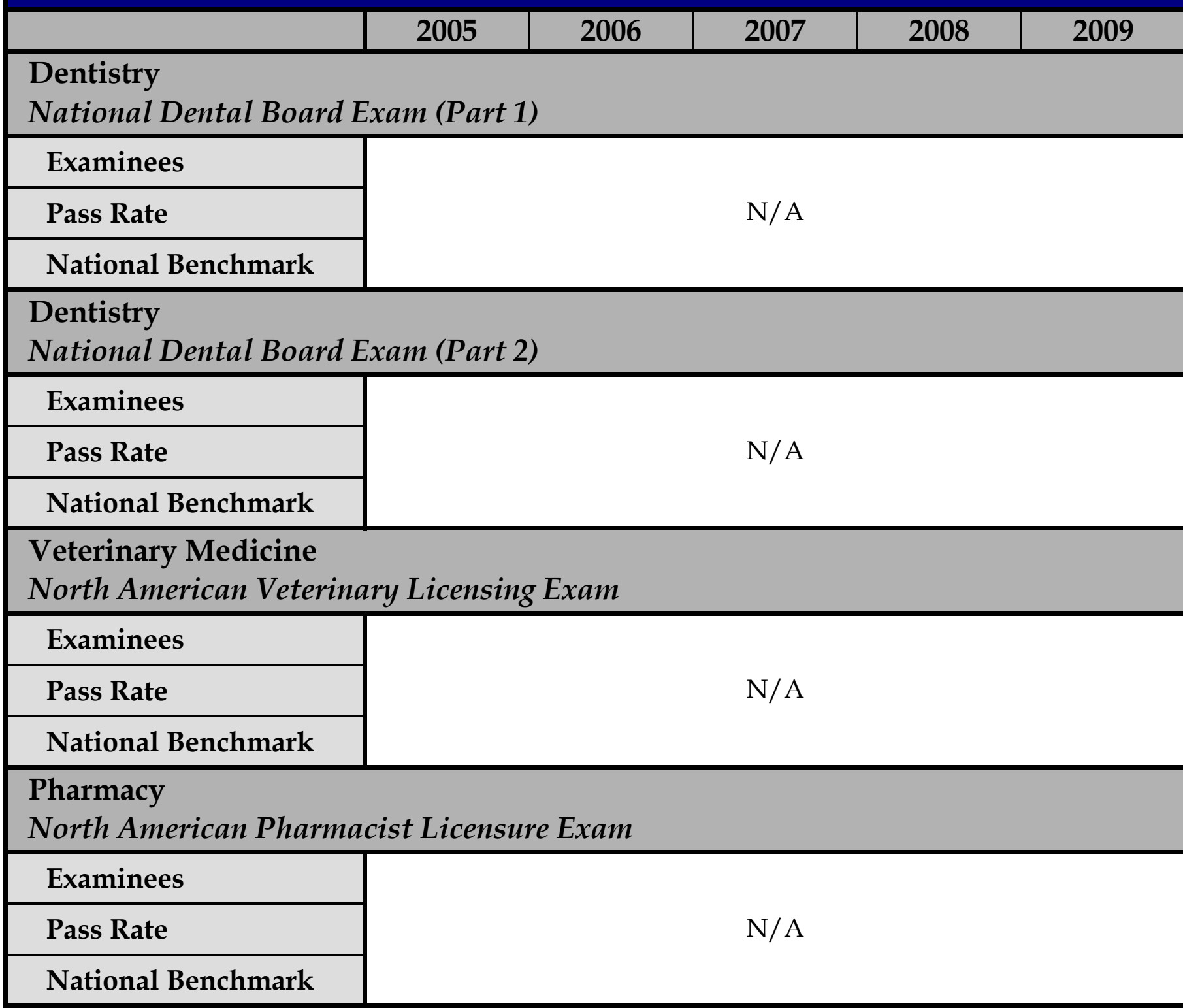

Note: All licensure data is based on first-time examinees. 


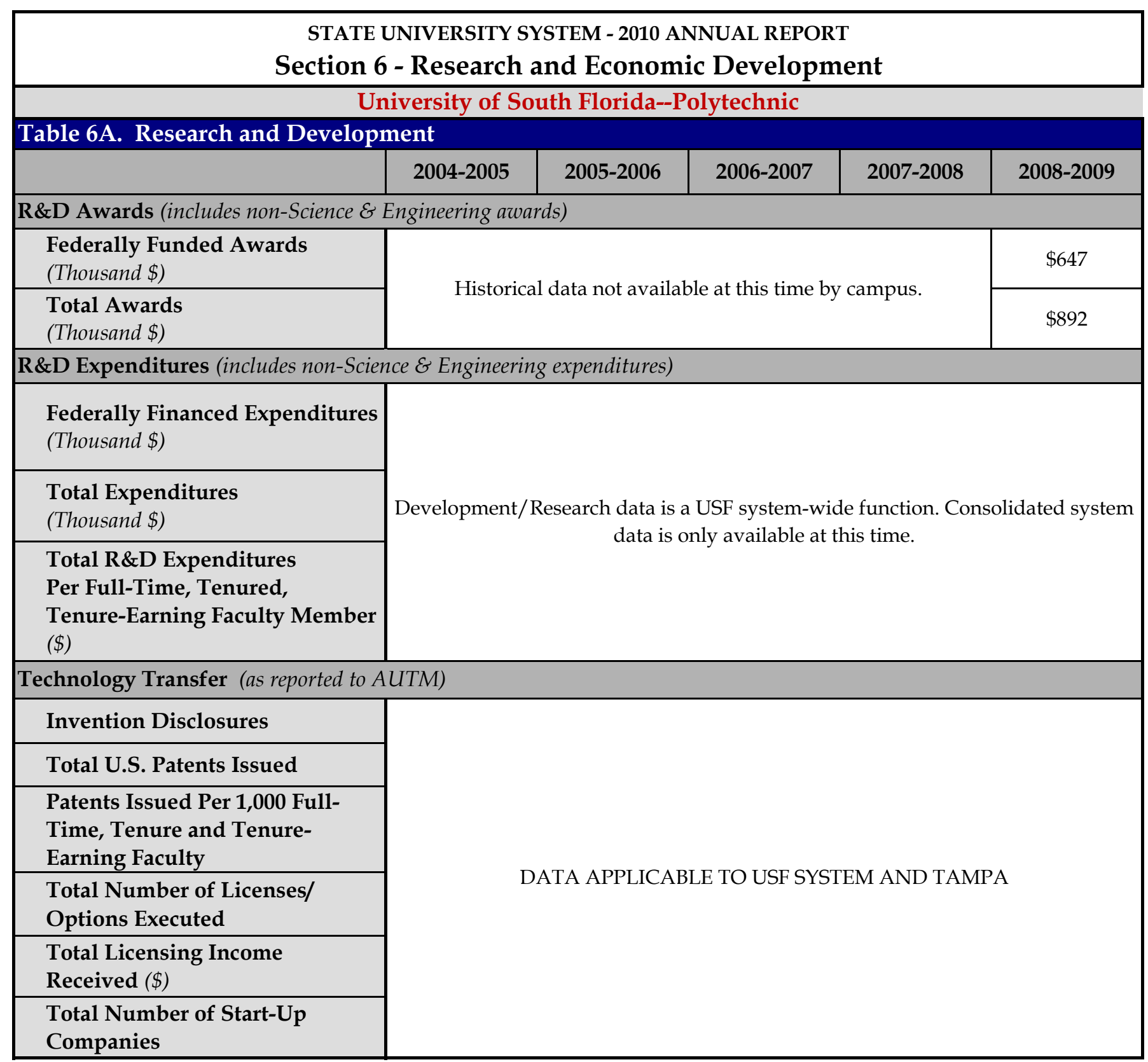




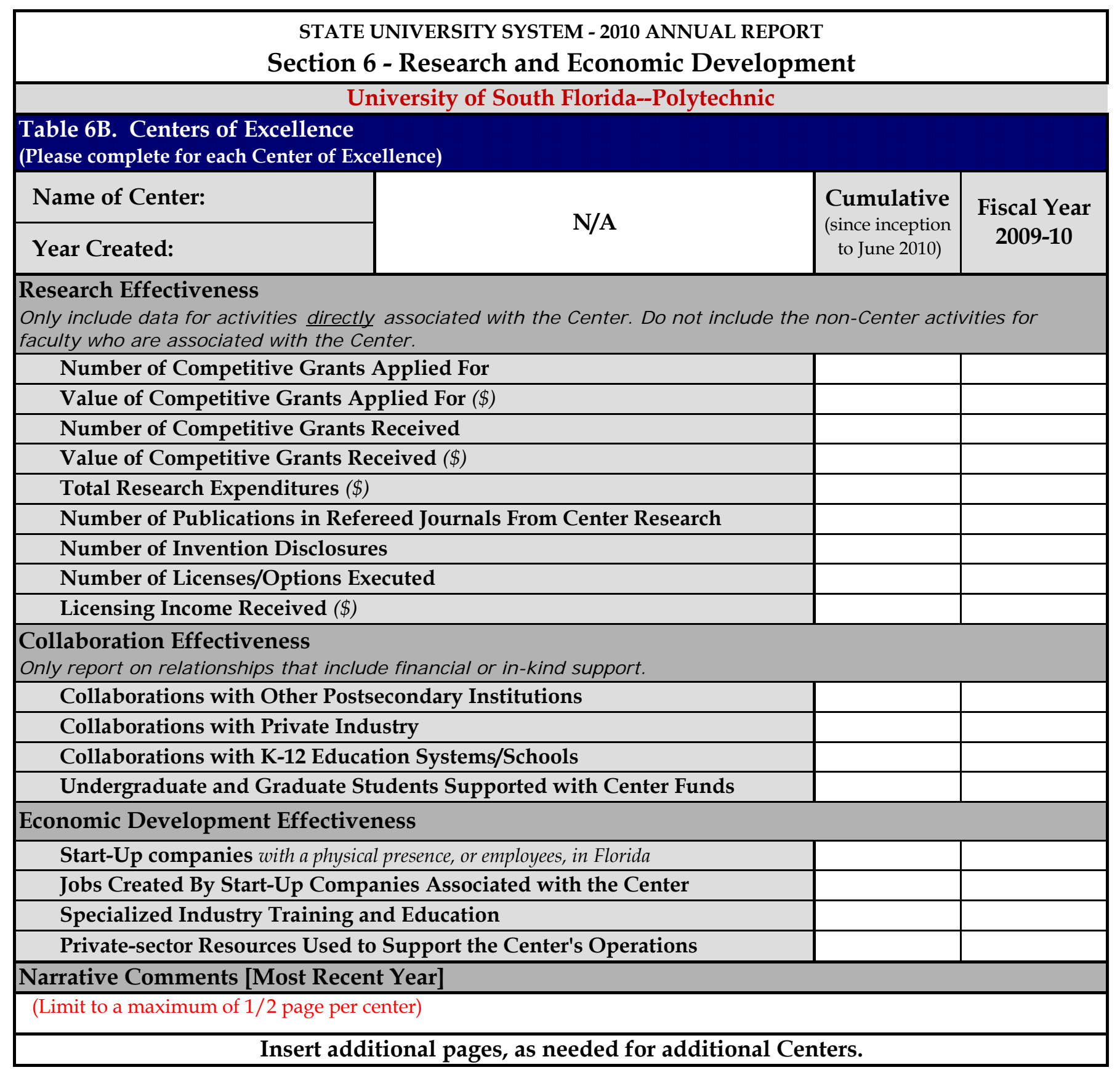




\begin{tabular}{|c|c|c|c|c|c|}
\hline \multicolumn{6}{|c|}{$\begin{array}{l}\text { STATE UNIVERSITY SYSTEM - } 2010 \text { ANNUAL REPORT } \\
\text { Section } 6 \text { - Research and Economic Development }\end{array}$} \\
\hline \multicolumn{6}{|c|}{ University of South Florida--Polytechnic } \\
\hline \multicolumn{6}{|c|}{ Table 6C. State University Research Commercialization Assistance Grants } \\
\hline \multirow{2}{*}{\multicolumn{4}{|c|}{ Project Name by Type of Grant }} & \multicolumn{2}{|c|}{ Cumulative } \\
\hline & & & & AWARDS & EXPENDITURES \\
\hline \multicolumn{4}{|l|}{ Phase I Grants } & & \\
\hline \multicolumn{4}{|l|}{ 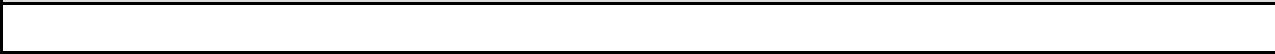 } & $\$ 0$ & $\$ 0$ \\
\hline \multicolumn{4}{|l|}{ Phase II Grants } & & \\
\hline \multicolumn{4}{|l|}{+2} & $\$ 0$ & $\$ 0$ \\
\hline \multicolumn{4}{|l|}{ Phase III Grants } & & \\
\hline \multicolumn{4}{|l|}{ 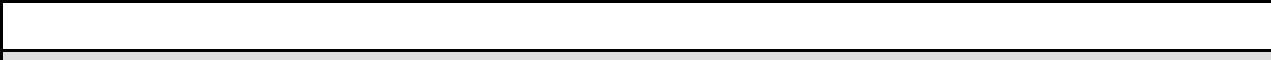 } & $\$ 0$ & $\$ 0$ \\
\hline \multicolumn{4}{|l|}{ Total for all SURCAG Grants } & $\$ 0$ & $\$ 0$ \\
\hline \multicolumn{6}{|l|}{ Narrative Comments } \\
\hline \multicolumn{6}{|c|}{$\begin{array}{l}\text { For each project, provide a brief update on: (1) the project's progre } \\
\text { and (2) the project's return on investment for the university and st } \\
\text { update on the project's ability to generate sufficient revenues to su }\end{array}$} \\
\hline \multicolumn{6}{|c|}{ Table 6D. 21st Century World Class Scholars Program } \\
\hline \multirow[b]{2}{*}{$\begin{array}{l}\text { World Class Scholar(s) } \\
\text { and Field }\end{array}$} & \multicolumn{2}{|c|}{ Grant Dollars } & \multicolumn{3}{|c|}{$\begin{array}{l}\text { Report the cumulative activity } \\
\text { since each scholar's award. }\end{array}$} \\
\hline & $\begin{array}{c}\text { Amount } \\
\text { Awarded } \\
\text { (Thousand \$) }\end{array}$ & $\begin{array}{l}\text { Cumulative } \\
\text { Amount } \\
\text { Expended } \\
\text { (Thousand \$) }\end{array}$ & $\begin{array}{l}\text { External } \\
\text { Research } \\
\text { Awards } \\
\text { (Thousand \$) }\end{array}$ & $\begin{array}{l}\text { Patents } \\
\text { Filed / } \\
\text { Issued }\end{array}$ & $\begin{array}{l}\text { Licensing } \\
\text { Revenues } \\
\text { Generated } \\
\quad(\$)\end{array}$ \\
\hline & & & & & \\
\hline & & & & & \\
\hline & & & & & \\
\hline TOTAL for all Scholars & $\$ 0$ & $\$ 0$ & $\$ 0$ & 0 & $\$ 0$ \\
\hline Narrative Comments & & & & & \\
\hline
\end{tabular}

